\title{
Erken Cumhuriyet Dönemi Türkiyesi'nde Asri Ev Tartışmaları ve Elektrikli Tenvirat
}

\author{
NURÇIN ILERI'1 ${ }^{1}$ CANSU DEĞiRMENCIOĞLU² \\ ${ }^{1}$ PhD, EUME Fellow, Forum Transregionale Studien ve Humboldt University, re:work \\ (IGK Work and Human Life Cycle in Global History) (Orcid ID: 0000-0002-2990-8042) \\ ${ }^{2}$ PhD Candidate, Technical University of Munich, Department of Architecture \\ (Orcid ID: 0000-0003-1949-3231)
}

\begin{abstract}
Özet
Türkiye'nin ulus-devletleşme sürecinde elektrik teknolojisi kullanımı endüstriyel ve kamusal mekânların yanı sıra ev içinde de teşvik edilmiş ve rasyonelleşmiş bir ev içi kültürü oluşturulmaya çalışılmıştı. Cumhuriyet'in elektrikle aydınlatılan yeni teşhir mekânları ise yeni bir gelecek vaadiyle bu mekânlarda bir araya gelen toplum bireyleri için hayranlık, iyimserlik, aidiyet ve birliktelik ruhunu yaratmayı hedeflemişti. Bu ruhun uzandığı asri ev de yeni rejimin teşhir mekânlarından birisi olarak kurgulanmıştı. Elektrikli aydınlatma kullanımının teşvik süreci, yeni rejimin arzuladığı rasyonel, bilimsel, verimli, ölçülü, sıhhatli, hijyenik vatandaş inşası süreciyle paralel ilerlemiş, hatta bu ürünler çağdaş kadın, erkek ve çocuk imgeleri eşliğinde sunularak, rejimin "asrilik" vurgusu böylelikle pekiştirilmek istenmiştir. Elektrik ışığı, bir yandan zamanın ruhunu evlerin içine taşırken diğer yandan yeni rutinler ve yeni nesnelerin birbiriyle kurduğu işlevsel bağı tamamlayıcı bir rol de üstlenmiştir. Böylelikle yönetici iktidarın hedeflerinin de ötesinde, elektrik teknolojisinin kendisi bir tarihsel aktör olarak evlerin içini dönüştürmüş, Cumhuriyet'in soyut modernizasyon söylemlerinin nesneleştirilmesinde kilit bir rol oynamış ve kendi materyal kültürünü yaratmıştı. Cumhuriyet'in ilk yıllarında ev içi mekânda elektrikli tenvirat kullanımının "asrileşme" çabalarını nasıı şekillendirdiğini söylemsel ve pratik düzeyde inceleyen bu çalışma, domestik mekânda elektrikli tenvirat kullanımını teşvik eden resmi ve popüler yayınlardan faydalanarak, uluslararası düzeyde de ilgi konusu olan fennî ve asri ev tartışmalarına interdisipliner bir yaklaşım getirmeye çalışmaktadır.
\end{abstract}

Anahtar Kelimeler: asri ev, elektrik, elektrikli aydınlatma, teknoloji tarihi, maddi kültür

Corresponding Author / Sorumlu Yazar

E-mail / E-posta

Manuscript Received / Gönderim Tarihi

Revised Manuscript Accepted / Kabul Tarihi

To Cite This Article / Kaynak Göster
NURÇIN ILERI

Forum Transregionale Studien, EUME

nurcinileri@gmail.com

August 15, 2020 / 15 Ağustos 2020

October 04, 2020 / 4 Ekim 2020

Ileri, N. \& Değirmencioğlu, C. (2020). Erken Cumhuriyet

Dönemi Türkiyesi'nde Asri Ev Tartışmaları ve Elektrikli

Tenvirat. ViraVerita E-Journal: Interdisciplinary

Encounters, Sayı 12, 92-126. 


\title{
Electrical Illumination and Debates on Modern House in Early Republican Turkey
}

\begin{abstract}
The formation of the nation-state in Turkey witnessed the use of electrical technology not only in industrial and public spaces but also in domestic ones as a target to bolster rationalized home culture. The newly electrically illuminated exhibition spaces of the Republican Turkey were promising and futuristic at the time. These spaces aimed to generate a spirit of progress, admiration, optimism, belonging, and togetherness among citizens who came together to see them. The modern home also reflected this new spirit and functioned as one of the exhibition spaces of the new regime. The promotion of the use of electrical lighting progressed in parallel with the aim of the new regime to make their citizens rational, scientific, efficient, logical, healthy, and hygienic. Moreover, the electrical commodities were advertised with the images of modern women, men, and children so that they could promote the regime's emphasis on "modernity". While electric light that represented the zeitgeist entered homes, it also played a complementary role in the interplay between new routines and objects. Outreaching the goals of the ruling regime and acting as an agent of change, electrical technology, therefore, transformed the home interiors while embodying the abstract modernization discourses of the Republic. In addition, it created a distinctive material culture. This study examines how the electrical lighting in domestic spaces shaped the efforts of "modernization" in the early years of the Republic at the discursive and practical level. By analysing official and popular publications that encouraged the domestic use of electric illumination, this study further aims to bring an interdisciplinary approach to contemporary debates on the rationalized and modern homes of the $20^{\text {th }}$ century.
\end{abstract}

Keywords: modern house, electricity, electrical lighting, history of technology, material culture, Turkey 


\section{Erken Cumhuriyet Dönemi Türkiyesi'nde Asri Ev Tartışmaları ve Elektrikli Tenvirat}

Hâkimiyet-i Milliye gazetesinin 20 Temmuz 1929 günü yayımlanan nüshasında “Modern Bir Ev Nasıl Döşenmelidir?" başlığıyla anonim bir yazar tarafından kaleme alınan bir metin, ev içi mekânı modern kılan unsurları şu şekilde tarif eder:

Salonu hafif, dağınık ve mat bir ışıkla aydınlatmak lazımdır, koltukların yanına ayrıca süslü masa lambaları koymak muvafık olur... Yatak odasının sıhhi ve rahat olması gerektiğini belirterek, geniş bir karyola, toz yuvası olamayacak düz eşya- tuvalet masası, komidin, gardırop ve bir iki sandalye, komidinin üzerine gölgelikli bir lamba... Oturma odasında gerek gün ışığı gerekse elektrik ışığı makbuldür, ayrıca bir de ayaklı lamba vardır. Alçak çay masası, renkli ve süslü yastıklar, avizeler odaya neşe ve hususiyet verir (Modern Bir Ev, 1929, s. 5).

Evlerde kullanılan eşyaların çeşitliliği, renkleri, sıhhiliği ve işlevlerinden kaynaklı görselduyumsal ayrıntılarıyla aktaran bu tasvirin benzerlerine aynı dönemde çıkan dergi ve gazetelerde sıklıkla rastlamak mümkün. Modern bir evin ne tür eşyalara sahip olması ve nasıl tertip edilmesi gerektiğine dair anlatıların veya çalışmaların erken Cumhuriyet dönemi için yeni olmadığını söylemeliyiz. Siyasi ve toplumsal çerçevede gerçekleşen askerlik, hukuk, sağlık ve eğitim alanlarında yaşanan birçok değişimin yanı sıra, domestik nesnelerin dönüşümünün de Osmanlı-Türk toplumunda moderniteyi tanımlayan unsurlardan biri olduğunu söyleyebiliriz. Osmanlı toplumunun bu nesnelerle kurduğu ilişkinin zaman içerisinde farklı anlamlar kazandığını da iddia etmek mümkün. Uğur Tanyeli, II. Mahmud döneminde (1808-1839) çoğunlukla Batı́dan ithal nesnelerin Osmanlı bürokrat ve elit sınıfının bir kamusal takdim nesnesiyken, geç on dokuz ve erken yirminci yüzyıllarda toplumun elit tabakası dışında da ilgi görmeye başladığını ve tek tek değil, iç mekânın organizasyonunda bütünsel olarak önem kazandığını iddia eder. Bu dönemde kentsel mekân ve konut dışı yapısal mekânlara kıyasla eve ayrı bir önem atfedildiğini ve özellikle edebi eserler aracılığıyla yeni çağdaş insanın yeni mikrokozmosu içinde kurgulandığını belirtir (Tanyeli, 1996, s. 291).

Edebi kurgularda genellikle örtük bir didaktizm ile konut iç mekânına ilişkin bir bilincin geliştirildiği bu anlatıların yerini yüzyıl sonundan itibaren sistematik bir biçimde çağdaş barınma ve yaşama modelleri sunmaya çalışan el kitapları ve ev idaresi kitapları alır. Ahmet Mithat Efendi'nin 1894'te kaleme aldığı ve henüz Osmanlı toplumunda yerleşmemiş olan Batı usullerini 
didaktik bir biçimde aktardığı Avrupa Adab-ı Muaşeret Yahut Alafranga adlı eseri bu kitapların ilkini teşkil eder. Ahmet Mithat'ın bu eseri yazmaktaki amacı, taklit hevesi neticesinde insanların birtakım şeyleri yanlış yapıyor olduğu savı ve onlara doğru olanı gösterme çabasıdır. 'Avrupa görgü kültürüne dair ayrıntılı gözlemlerin yer aldığı bu kitapta, yazar küçük veya büyük salonların düzeninde ve süslenmesinde dikkat edilmesi gereken en önemli hususun tenvirat yani aydınlatma olduğuna dikkati çeker:

Bir salonu tezyin [süsleme] hususunda en büyük ehemmiyet tenvirat meselesindedir. Tenviratta ve daha doğrusu vesait-i tenvîriyede ne kadar kesret olur [çokluk] ise o kadar kibarlık sayılır. Fakat asıl kibar olan yerlerde ne hava ne de petrol gazı salonlara kabul olunmayıp lambalar ve koleza yağı ile yanar cinsten vaz'olunur. Halen vesait-i tenvîriyenin en şık ispermeçet mumları olup büyük salonlardan başka yerlere elektrik ziyası bile henüz ithal olunmamıştır. Vesâit-i tenvîriye şamdan ve gerek tek ve gerek müteaddid [çeşit çeşit] mumlu fanuslu fanussuz masalar üzerine konur veya duvarlara çakılır nev'inden her nevi şamdanlar ile avizelerden ve bir de lambalardan ibarettir. Lambalar üzerine kâğıt ve kumaştan mamul mütehâlif [birbirine uymayan] şekillerde rengarenk abajurlar dahi koyarlar. Vesâit-i tenvîriyenin kesreti süs sayıldığından ekserisi yakılmayacak olduğu halde dahi münasebetli münasebetsiz yerlere bunları doldururlar. Bir salonun tezyinatı medh olunacağı zaman bilhassa “(...) nev tenvir olmuş idi," derler ki, gündüz gibi tenvir edilmiş olduğunu beyan demektir (Ahmet Mithat, der. Doğan ve Gurbetoğlu, 2001, s. 155).

Ahmet Mithat'ın 1894'te yazdığı ve girişte değindiğimiz 1929 tarihli satırların ortak noktası, bir evi modern kılan unsur olarak aydınlatmanın önemidir. Ancak farklı tarihlerde kaleme alınmış olan bu anlatıların aydınlatmaya yaptığı vurgunun içeriğinin değiştiğini görmek mümkün. Ahmet Mithat, henüz elektriğin büyük salonlar dışında pek kullanılmadığı, mum, gaz ve petrolün kullanıldığı aydınlatma vasıtalarının ise çeşitli ve bol olduğu, temel olarak bu vasıtaların işlevinin evi süslemek olduğu bir dönemi resmeder. Bu resmedilen görüntü karşısında öne çıkan bir hayranlık söz konusudur. Erken Cumhuriyet döneminin modern evi betimleyen satırlarında ise bu hayranlıktan uzaklaşıldığını ve aydınlatma vasıtalarının ölçülü, sıhhi, temiz, konforlu ve psikolojik etkileri de göz önünde tutularak belli bir düzen içinde, işlevleri daha net tanımlanmış elektrik aydınlatması ve vasıtaları görürüz. Dolayısıyla erken Cumhuriyet döneminde modern/asri ev ve iç mekân aydınlatmaya dair tartışmaların Osmanlı'daki adabı muaşeret anlatılarıyla benzerlikler içerdiğini, ancak bir yandan da imparatorluktan ulus-devlete geçiş 
sürecinde yeni Cumhuriyet rejiminin hedefleri doğrultusunda farklı anlamlar çerçevesinde ilerlediğini söyleyebiliriz.

Bu makalede erken Cumhuriyet döneminde konut iç mekânında elektrikli tenvirat kullanımının "asrileşme" çabalarını söylemsel ve pratik düzeyde nasıl yansıttığını incelemeye çalışacağız. Bu doğrultuda ilk bölümde Türkiye'nin elektriklendirilme sürecine, Cumhuriyet rejimi aydınları, mimar ve mühendislerinin asri evi nasıl resmettiğine ve bunun anlamlarına dair tarihsel bir çerçeve sunmayı hedefliyoruz. İkinci bölümde ise dönemin dergi ve gazetelerinde yer alan elektrikli tenvirat ürünlerinin nasıl bir söylem eşliğinde pazarlandığı ve bunun gündelik pratiklerde neye tekabül ettiğini reklamlar, tanıtımlar ve tasarım ortamındaki asrilik açılımları üzerinden tartışmaya açacağız. Gündelik hayat pratiklerini temel alan çalışmalar bir toplumun materyal kültür çalışmalarına katkı sunabileceği gibi, bu gündeliklik dönemin küresel, politik, teknik ve kültürel dinamikleriyle ilintilendirildiğinde o topluma dair daha büyük bir resmi de görmemizi sağlar (Lefebvre, 2007, s. 40). Bizim de bu makaledeki amacımız ev içi mekânda elektrikli aydınlatmanın tanıtımı ve kullanımını temel alarak, Cumhuriyet modernleşmesi, teknoloji tarihi ve materyal kültür arasındaki ilişkiyi açığa çıkarmak.

Türkiye'nin elektriklendirilmesi sadece teknolojik bir gelişme olarak değerlendirilemez; erken Cumhuriyet döneminde ivme kazanan bu süreç yeni rejimin toplumsal, ekonomik ve politik ajandaları tarafından şekillenmiş ve aynı zamanda bu ajandaları şekillendirmiştir. Türkiye'nin ulus-devletleşme sürecinde elektriğin endüstriyel ve kamusal mekânlarda kullanımının yanı sıra ev içinde de kullanımı teşvik edilmiş ve rasyonelleşmiş bir barınma kültürünün oluşturulması hedeflenmiştir. Günümüzde materyal kültür çalışmaları nesnelerin önemini sadece onların ekonomik rolleri üzerinden değil, -genellikle birçok sosyal ve fennî disiplinde arka plana itilmiş- bir değer, inanış, kolektif bilinç veya toplumsal yapıyı oluşturan ve dönüştüren kültürel rolleri üzerinden de tanımlama çabası içindedir (Appadurai, 1986; Vanini, 2009). Bu makalede de elektrikli tenvirat ve ürünlerinin muhtemel anlamları çerçevesinde oluşan asri ev kültürünü ve bu kültürün Cumhuriyet rejimi ideolojisinin söylemleriyle ne tür paralellikler gösterdiğini irdeleyeceğiz.

Bu amacımızı gerçekleştirebilmek için dönemin resmi ve popüler dergi ve gazetelerinde (Hakimiyet-i Milliye, Ameli Elektrik, Yedigün, Arkitekt gibi) yer alan yazılardan faydalanmayı planlıyoruz. Bu kaynaklar modernleşme, asri ev, elektrik ve tenvirat tartışmalarına dair dönemin farklı toplumsal tabakalarının fikir dünyasını yansıtan zengin bir içeriğe sahip. Ayrıca Türkiye'de modernleşme projesini anlamamıza katkı sunacak zengin bir görsel repertuar oluşturan 
reklamları da içeriyor. Çok uluslu şirketlerin ürünlerinin tanıtıldığı bu reklamlar şüphesiz daha geniş kitlelere hitap eden, tek bir ulus veya coğrafya ile sınırlandırılamayacak evrensel bir dile sahip. Bunu bir engel olarak görmenin aksine, Türkiye gündelik kültürüne de uyarlanmaya çalışan bu reklamların 1920'lerden itibaren Türkiye'nin kolektif bilincinin oluşmasında oldukça etkili olmuş kurumsal, ritüel, sembolik ve estetik göstergeler olarak (Bozdoğan ve Kasaba, 1997, s. 5) çalışmamızı beslediğini düşünüyoruz.

\section{Elektrikli Türkiye, Asri Ev, Muasır İnsan}

On dokuzuncu yüzyılda elektrik, Sanayi Devrimi'nin ihtiyaç duyduğu yeni enerji rejiminin itici gücü olmuş ve Batı emperyalist politikalarının bir neticesi olarak ulaşım, aydınlatma, iletişim ve sağılk gibi alanlarda kendisine yeni pazar ve kullanım alanları yaratmıştı (Bodanis, 2004; Hughes, 1993). Yirminci yüzyılın ilk yıllarında ise elektrik, elektrik ışığı, elektrikle hareket ettirilen ve kumanda edilen nesneler gece ve gündüzün sınırlarını muğlaklaştırmış ve görsel-işitsel, pratikduyumsal olanın kavranışını zenginleştirerek gündelik hayatın ritmini değiştirmeye başlamıştı (Lefevbre, 2007, s. 127).

Elektrik teknolojisi dünyanın bazı büyük kentlerinde endüstriyel, kamusal ve hane içi mekânlarda yavaş yavaş kullanım alanı bulurken, bu yeni teknolojiye Osmanlı coğrafyasında altyapısal, finansal ve politik nedenlerden ötürü şüpheyle yaklaşılmıştı (Engin ve Gülsoy, 2010; Öztaner, 2016). ${ }^{i i}$ Osmanlı Devleti'nin başkenti özelinde örnek verecek olursak, İstanbul'un elektriklendirilmesi imtiyazı için girişimler 1870 'lerin sonunda başlamıştı. Fakat ilk kent ölçekli santralin kurulması ve elektrikli tramvay alt yapısının oluşturulması imtiyazı, ancak 1910 yılında Nafia Vekâleti tarafından Avusturya-Macaristan Ganz Şirketi'ne 50 seneliğine verilebilmişti.iii Kentte elektrik altyapı şebekesi inşasına girişilmiş, Silahtarağa Elektrik Santrali inşaatının bir kısmı 1913 yılında tamamlanmış ve santral 1914 yılında tramvay ulaşımı ve özel/kamusal aydınlatma için elektrik üretimi ve dağıtımına başlamıştı. ${ }^{\text {iv }}$ Ancak, elektrik santralinin inşası, altyapı çalışmaları sırasında Trablusgarp ve Balkan Savaşları, sonrasında ise Birinci Dünya Savaşı ve Kurtuluş Savaşıının ortaya çıkardığı sorunlar neticesinde elektrik üretiminde sıkıntılar yaşanmıştı. Bu teknolojinin altyapısını mümkün kılacak olan ham madde ve alet-edevat transferinin gerçekleşememesi de bu sıkıntıları tetiklemişti. Dolayısıyla İstanbul'un elektrik üretimi yapan tek kent ölçekli santrali tarafından üretilen elektriğin yeni alt şebekesi ile sistematik bir şekilde üretimi, dağıtımı ve tüketimi 1920'li yılları buldu. İstanbul'da tarihi 
yarımada ve Avrupa yakasından sonra Silahtarağa Elektrik Santrali elektrik şebekesi, 1925 'ten itibaren Anadolu yakasında, Üsküdar, Kadıköy, Maltepe, Kartal ve Pendik taraflarını içine alacak biçimde genişletilmiş; 1930'lu yılların başında ise Büyükada ve Heybeliada elektriğe kavuşmuştu. Elektrikten faydalanmak isteyenlerin sayısı da günbegün artmaktaydı. 1921'de 21.658 olan abone sayısı 1923 yılında şebekenin de uzamasıyla 30.228'e çıktı, 1926'da ise 40.640'a ulaşmıştı, 1928'de ise 50.000 civarı abone vardı. İstanbul'un nüfusunun 1927 sayımlarına göre 806.860 olduğunu düşündüğümüzde, nüfusun \%5,8'i kadar elektrik abonesi olduğunu söyleyebiliriz (Umûmî Nüfûs Tahrîri, 1927, s. 3). Sanayi müesseselerinin, atölyelerin, imalathanelerin, fabrikaların elektrik enerjisinden faydalanmaya başlamasının bu artışta önemli rol oynadığını söylemek mümkün. Her ne kadar elektrik üretimi ve dağıtımı ilk etapta sınai üretim amaçlı olmasa da ve daha çok kamusal ve ev içi kullanım hedeflense de, fabrikalar elektrik santralinin önemli müşterileri haline geldiler. ${ }^{\vee} 1928$ 'de elektrik şirketinin irili ufaklı yaklaşık 1850 fabrika abonesi bulunuyordu (İstanbulda elektrik kuvvei, 1929).

Türkiye geneline baktığımızda Cumhuriyet rejiminin Osmanlı Imparatorluğu'ndan devraldığı elektrik enerjisinin sadece 30,345 kilovat saatlik potansiyele sahip olduğunu görüyoruz. Ülke nüfusunun \%94'lük kısmı henüz elektriğe kavuşamamıştı, kişi başına düşen elektrik üretimi ise 5 kilovat saat ile sınırlıydı. 1929 yılına kadar irili ufaklı 97 elektrik santrali inşa edilmişti (İstatistik Yıllığı, 1931-1932, s. 225). vi Hakimiyet-i Milliye gazetesinin 29 Ekim 1933 günü çıkan nüshasında, Cumhuriyet rejiminin kent, altyapı, eğitim ve sağlık alanında gösterdiği gelişmeler aktarılırken 1928 ve 1932 arası elektrik üretimi ve tüketimi oranlarına da yer verilmişti.

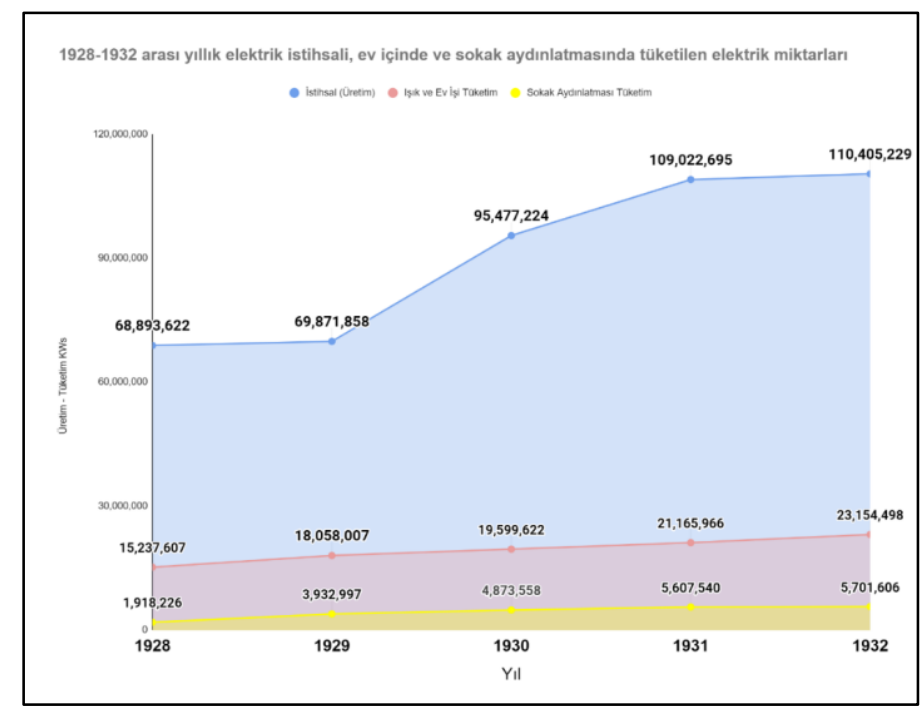

Figür 1. Türkiye Genelinde Elektrik İstihsali ve Sokak Aydınlatması ile Ev İçi Tüketime Harcanan Elektrik Miktarları (Hakimiyet-i Milliye, 29 Ekim 1933, s. 36). 


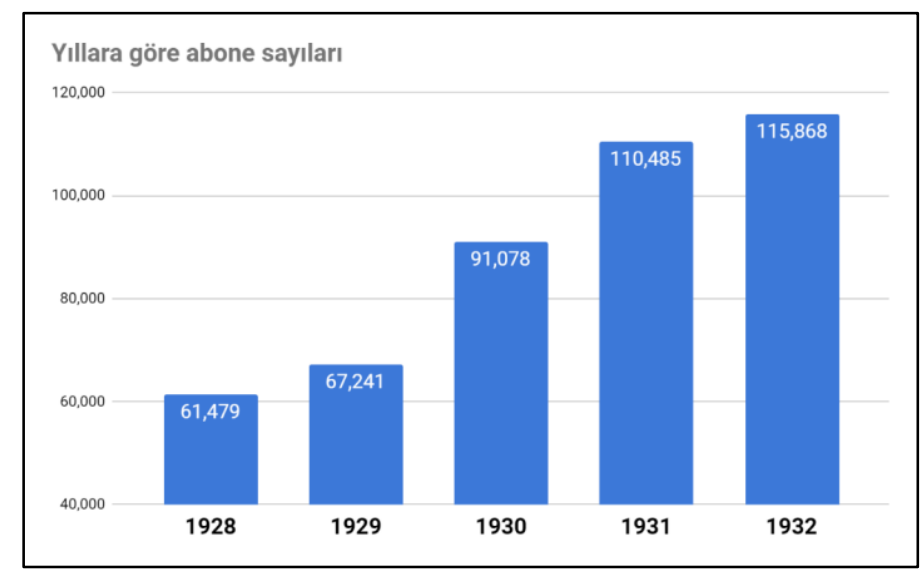

Figür 2. Türkiye Genelinde Işık ve Ev İşlerinde Abone Sayısı (Hakimiyet-i Milliye, 29 Ekim 1933, s. 36).

1933 yııında, kişi başına düşen elektrik üretimi miktarı 8,8 kilovat saate ulaşmıştı. Türkiye genelinde elektrik üretimi, elektrik abone sayısı ve evlerde elektrik tüketimi arasında doğru orantılı bir artış gözlemleniyor olsa da, ev içinde elektrik kullanımından faydalanabilenler toplumun orta ve üst tabakaları oldu, toplumun büyük bir kesiminin elektrikten faydalanabilmesi için uzun yıllara ihtiyaç vardı. Elektriğin varlığı ve yokluğundan kaynaklı toplumsal eşitsizlikler ve buna bağlı şikâyetler ise günbegün dergi ve gazetelerin halk sütunlarına veya edebi eserlere yansıyordu. Örneğin Yakup Kadri Karaosmanoğlu, Ankara romanında ana karakterlerden Neşet Sabit'in evine dönerken bir caddede karşılaştığı elektrik ışığının şaşaası karşısında yaşadığı hisleri ve bunun keskin bir biçimde açığa çıkardığı sınıfsal eşitsizliği şu şekilde aktarır:

Genç adam önüne rastgelen ilk sokağa sapmazdan evvel, dönüp arkasına baktı. Aşağıdaki caddenin elektrik aydınlıkları, buraya kadar aksediyordu. Neşet Sabit, hatırladı ki, İstiklâl Harbi esnasında da evine geç döndüğü akşamlar, Çıkrıkçılar Yokuşu'nun başından istasyonun bir avuç elektrik aydınlığına böyle dönüp uzaktan bakardı. Fakat o bakışla bu bakış arasında, şimdi ufak bir fark vardı. Eskiden, Neşet Sabit, istasyonun lambalarını, alelade bir medeniyet hasretiyle seyrederdi. Şimdi ise, bunlara, bir fukaranın bir zengin malına bakışı gibi bakıyordu. "Şimdi, ben, bu karanlık sokaklarda, ayağımı taştan taşa çarparak yürürken Selma Hanım'ın salonunda dans edenlerin ayakları ayna gibi parlayan parkelerin üstünde akisler yapıyor ve aşağıdaki büyük caddenin iki yüz elli voltluk ampulleri sabaha kadar hiç kimsenin yolunu aydınlatmamak için yanacak... Garp medeniyetinin ne acayip, ne akıl almaz bir taksimi!" dedi. İçinden acı acı güldü. Biraz sonra yorgun argın ve hava ıslaksa paçaları çamurlara bulanmış, kuru ise toza ve gübreye batmış olarak oturduğu eve vuracak, kapısını bir kocaman paslı anahtarla açacak; kavrulmuş soğan ve çirkef suyu kokan 
bir karanlık avludan geçecek; başını, ayağını oraya buraya çarparak yattığı odaya çıkacak ve uzun bir müddet el yordamıyla kibriti, lambayı bulup nihayet, kirli bir ışığın bulanık aydınlığında kendisine mukadder olan şüpheli bir rahata kavuşacaktı. Oturduğu mahallede, henüz hiçbir evin ne elektriği, ne suyu vardı. Elektrik çok pahalıya mal oluyor, yanaşılmaz bir lüks telâkki ediliyordu. Suya gelince, onun tesisatı henüz bitmemişti (Karaosmanoğlu, 2004, s. 123-24).

İstiklal Savaşı sırasında Neşet Sabit için medeniyeti simgeleyen istasyonun ışıkları, yıllar içinde toplumun farklı sınıfları arasında eşitsizliği ve adaletsizliği görünür kılan ışık huzmelerine dönüşmüştü. Dönemin meslek erbabı ve siyasetçileri de elektriğin belli sınıf profillerini aydınlatırken diğerlerini daha da karanlıkta bıraktığının farkındaydılar. Mühendis ve siyasetçi Mehmet Şevki Yazman da 1933 yılında Kadro dergisinde kaleme aldığı "Elektrikli Türkiye" başlıklı yazısında elektriğin Türkiye toplumunun daha geniş bir kesiminde kullanılması gerektiği arzusunu dile getiriyor ve yazının geri kalanında bunun için çeşitli çözüm önerilerinde bulunuyordu:

Türkiye'nin elektriklenmesini istiyoruz. Çünkü Türkiye'nin elektriklenmesi demek Zonguldak'ta toprak altında duran kömürün veya Toros'ta yüksek kayalardan düşen suyun Türk iktisadiyatına hizmetçi kılınması demektir. Biz elektriği yalnız Türk şehrinin süslenmesi değil, karanlık Türk köyünün ışıldaması, geri teknikli Türk tezgâhının ileri teknikli bir fabrikaya çevrilmesi, Türk malının elektrikle işlenerek daha temiz, daha ucuz çıkarılması için istiyoruz. Hulâsa elektriği bir süs değil, iktisadımıza hizmet eden bir fazla kudret olarak istiyoruz. Ucuz, her tarafta ve herkes tarafından kullanılabilir bir hale gelmesini istiyoruz (Yazman, 1933, s. 35).

Her ne kadar Türkiye'nin elektriklendirilme çalışmalarında hedeflenen seviyeye pratikte ulaşılamamış olsa da, gerek endüstriyel ve kamusal alanda gerek hane içinde yaygınlaştırılmaya çalışılan elektrik enerjisi ve teknolojisi, yeni Cumhuriyet rejiminin ilerleme çabalarının somutlaşmasında önemli bir rol oynadı. Sibel Bozdoğan'ın (2002, s. 145-147) da iddia ettiği üzere, elektriği uygarlığın bir öznesi, sınai ilerleme ve ekonomik kalkınmanın katalizörü olarak resmeden Cumhuriyet rejimi, "aydınlanma" terimini hem düz hem de metaforik anlamda benimsemişti, dolayısıyla elektriğin kamusal kullanımı oldukça önemliydi. Cumhuriyet elitlerinin nezdinde Osmanlı siyasi rejimini temsil eden karanlığın fethi, aynı zamanda cehaletin ve âdemi emniyetin ortadan kaldırılması anlamına gelmekteydi. Örneğin, Cumhuriyet'in onuncu yılı vesilesiyle, birçok etkinlik organize edilmiş; gündüz çeşitli konferanslar ve yürüyüşler yapılırken, 
geceyse hükümet, abidelerin, resmi müesseselerin, parkların tenviratı ve bu ziya dalgaları ile ortaya çıkabilecek her türlü tesiri göstermek için çaba harcamıştı. Bu etkinlikler kapsamında halktan evlerinin önünü elektrik lambası ile aydınlatması da talep edilmişti (Dinçel, 1973, s. 93).

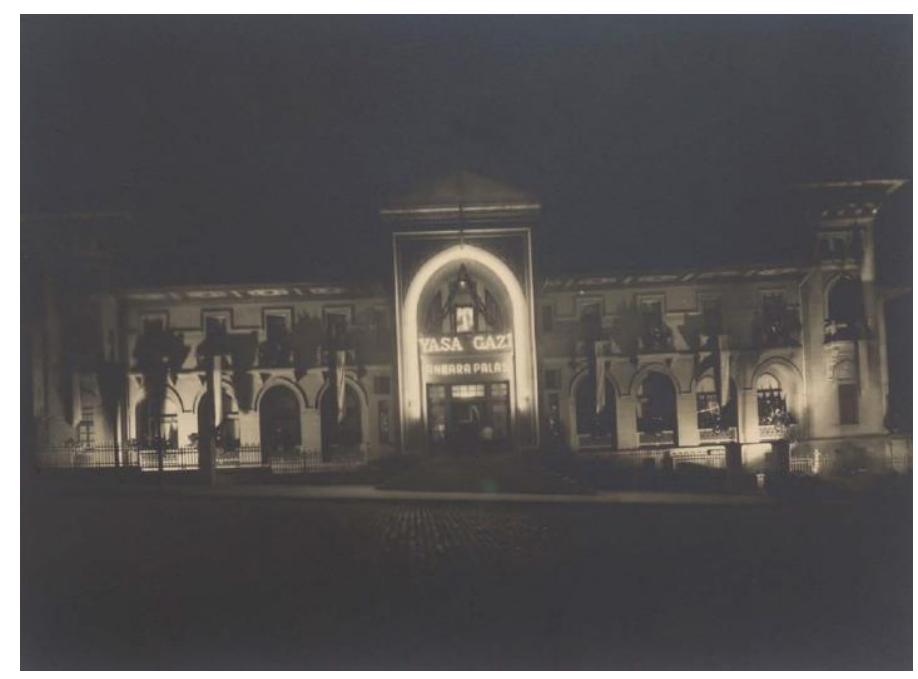

Resim 1. Ankara'da 1933 yılı vesilesiyle aydınlatılan bina cephesi (Kaya, t.y., TBMM Kütüphane ve Arşiv Hizmetleri Başkanlı̆̆ı).

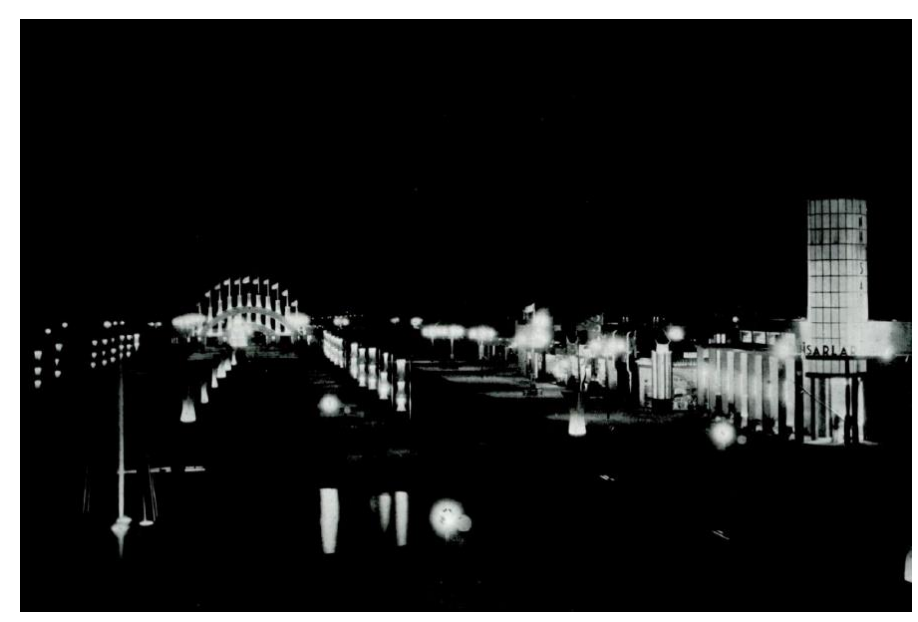

Resim 2. Rejimin propaganda yayını La Turquie Kamâliste'de (1936) yayımlanan 1936 İzmir Fuarı́nın gece görünüşü.

Şüphesiz, daha önceki yüzyıllarda da başka vasıtalar (mum, kandil, gaz yağı, petrol, havagazı) aracılığıyla sokakların, kamusal mekânların veya hane içlerinin, asayişi temin edebilmek, kutlama yapmak veya süsleme amacıyla aydınlatılması söz konusuydu. Özellikle iyi bir tenvirat süslemesi dini bayramların, şehzadelerin doğum ve evlilik günleri, sünnet düğünleri gibi hanedana ilişkin mutlu olayların vazgeçilmez bir parçasıydı (Kafadar, 2014; Karateke, 2015). Padişahın tahta çıkış törenlerinin kutlanması geleneği ise II. Mahmud döneminde başlamış, II. Abdülhamid (1876-1909) döneminde ise her yıl özel bir şatafatla kutlanılan bir devlet 
bayramına dönüşmüştü. François Georgeon, Sultan Abdülhamid'in her sene 1 Eylül'de kutlanan tahta çıkış törenini şu şekilde aktarır: "O gün kamu binaları ışıklandırılır ve üzerinde "Padişahımız çok yaşa!" yazan büyük panolarla süslenir. Büyük mağazaların, restoranların, bankaların, tiyatroların cepheleri ışıklı yazılarla kaplanır. Önemli şahsiyetler konaklarını, köşklerini veya yalılarını süslemek ve ışıklandırmak konusunda birbirleriyle yarışırlar" (Georgeon, 2006, s. 400). II. Abdülhamid dönemi törenlerinde yapılan aydınlatmanın temel kaynağı havagazıydı, ama ona çok sayıda kandil, kâğıt fenerler ve havai fişekler eşlik etmişti. Anlaşılacağı üzere aydınlatma pratiği, iktidarın kendi varlığını ve gücünü pekiştirme ve tebaanın iktidara sadakatini kanıtlama aracı olarak daha önceki yüzyıllarda da söz konusuydu (ileri, 2017; Wishnitzer, 2014). On dokuzuncu yüzyılın ikinci yarısından itibaren, sınai havagazı kullanımına başlanmış ve daha çok bireyler ve mahalle cemaatleri kontrolünde kalan küçük ölçekli aydınlatma veya ısıtma pratikleri belediye kontrolünde, kimi zaman yine yabancı şirketler aracılığıyla icra edilmeye başlanmıştı. Ancak hem devlet arşivleri hem de popüler yayınlarda bu kentsel hizmetlerin yetersizliğine ve oldukça sınırlı kaldığına dair ahalinin şikâyetlerini içeren birçok anlatı mevcut (ileri, 2017). 1908 devriminden sonra ise altyapı faaliyetleri hız kazanmış, uzun süren savaş dönemleri dolayısıyla kesintiye uğramıştı. Cumhuriyet dönemini daha önceki süreçlerden ayrıştıran ise tüm ülkenin elektrik enerjisine kavuşabilmesi için verdiği sistematik ve söylemsel düzeyde kalsa da eşitlikçi çabadır. Fabrikalar, sokaklar, kamusal parklar gibi elektrik kuvvetiyle işleyen veya aydınlatılan Cumhuriyet rejiminin teşhir mekânları yeni ulus ve bu ulusun vaadetiği gelecek karşısında, yeni Türkiye toplumunda, hayranlık, iyimserlik, ilerleme ve birliktelik ruhunu yaratmayı hedefliyordu (Bozdoğan, 2002, s. 149).

Cumhuriyet rejiminin arzuladığı bu ruh kamusal mekânlarla sınırlı kalmamalı evlere uzanmalıydı. Dolayısıyla erken Cumhuriyet dönemi barınma çevresindeki günlük yaşantının dönüşümünü de odağına almıştı. İdeal bir yeni adam, yeni kadın, yeni çocuk; kısacası yeni birey/vatandaş vurgusunun yoğunlaştığı bir dönemde evin rasyonel bir biçimde yeniden organizasyonu da gündemdeydi. Yael Navaro-Yaşın'ın (2000, s. 51-52) da belirttiği üzere bu rasyonelleştirilmiş ev hamlesi, uluslararası ev yapımı hareketi ile eş zamanlıydı. ABD ve Avrupa'daki ev ekonomistleri, Frederick Winslow Taylor'un endüstriyel verimi arttırmaya yönelik "zaman ve hareket" çalışmalarının, evlerde de uygulanabileceğini tartışıyorlardı. Fennî ev kurma ve ev içi verimlilik eksenli yapılan tartışmalar Cumhuriyet rejiminin ideologları, aydınları, mimar ve mühendislerince de ilgi görmüş ve asri Türk hanesi, asri ulus-devleti tamamlayan bir unsur olarak ele alınmıştır (Navaro-Yaşın, 2000). 
"Asrilik", farklı otoritelerce farklı anlamlar yüklenebilen bir kavramdı. Çağa ayak uydurma yolunda gerçekleşen kültürel değişimlerin milli karakterle olan ilişkisi cumhuriyet aydınları arasında her zaman tartışılan bir konu olsa da, asri olmanın bilimsel ve evrensel kabullerle, teknolojiyle, pragmatizmle kurulan bağı üzerinde adeta uzlaşılmıştı. Öte yandan, ulaşılmak istenen hedefler yalnız evrensellik ve rasyonellik değildi. Kültürel üretimin hemen her alanını seküler ve rasyonel bir eksende dönüştüren bilim, pozitivist cumhuriyet elitinin toplumun hayat tarzını değiştirmeye yönelik radikal müdahalelerini toplumun gözünde meşrulaştıran etkili bir araç olarak karşımızdaydı (Kanıpak, 1998, s. 54; Karaca, 2008, s. 197). Örneğin, sanat, sosyoloji, eğitim ve pedagoji alanlarında çalışmalar yapan cumhuriyet aydını İsmail Hakkı Baltacıoğlu, yapılı çevrenin estetik dönüşümü hakkında kaleme aldığı "Mimaride Kübizm ve Türk Ananesi" başlıklı yazısında, asri evin bilimsellikle ilişkisini şu şekilde tarif ediyordu:

\footnotetext{
Muasır insanı temyiz eden zihniyetin evleri fabrikaları nelerdir? Muasır insan her şeyden evvel ilme inanan ve ilimle amel eden bir insandır. İlim muasır cemiyetlerde içtimai bir müessise mevkiinde dinin yerine geçmiş gibidir. Maddi hayatımızı, ahlaki ve intifai amellerimizi idare eden amirler hep ilmindir. Hâlbuki ilim bize hava, güneş ve temizlik unsurlarından mürekkep bir sıhhatın müspet fikrini kazandırmıştır. Muasır insanın meskeni aynı zamanda havadar, güneşli, temiz olmalıdır (Baltacıoğlu, 1929, s. 118).
}

Dönemin popüler kadın ve yaşam tarzı dergilerinden Yedigün'de ise, "Ev ve Eşya" gibi dekorasyon köşelerinde, ABD ve Avrupa'dan iç mekân imajlarıyla beraber evlerin nasıl döşenmesi gerektiği konusunda tavsiyeler veriliyordu. Bu metinlerde "asri ev", "asri eşya" ve "asri mobilya" ifadeleri çokça yer alıyor, bunlar da özetle rahatlık, sadelik, temizlik ve kullanışlılık gibi kriterlerle açıklanıyordu. Örneğin, "asri bir yatak odası", sıhhi olduğu kadar basit ve güzel olarak tanımlanıyordu (Asrî bir yatak odası, 1934). Elektrik Şirketi'nin dergisi Ameli Elektrik'te yer alan "Evi asrileştirmek için" başlıklı yazıda, mimari bakımdan eski olan evlerin, elektrik tesisatı ile asrileştirilebileceğinden bahsediliyordu (1929). Dönemin mimarlık dergisi Arkitekt’te tenvirat konusunda yazılar yazan elektrik mühendisi Hasan Halet (Işıkpınar) (1931), modern bir ev hayatının ancak elektrik aydınlatması ile mümkün olabileceğini şöyle dile getiriyordu:

Yirminci asır hayatımızın her bir safhasını değiştirdi. Bugün tamamile başka bir zevki ve istirahatı bize temin eden yeni evlerde yaşıyor ve modern mobilyanın ahenktar heyeti içinde konforumuzu tatmin ediyoruz. Evimizdeki hayatımızdan azamî zevki 
alabilmekliğimiz için bugün yeni ve pek mühim bir amili de nazari itibara almağa mecburuz. Bu da zevk ile tertip edilmiş fennî bir tenvirattır. (Işıkpınar, 1931).

Görüldüğü üzere, Türkiye'nin elektriklenmesini teşvik eden devlet yayınlarına ve cumhuriyet ideologlarının anlatılarına, elektriğin gündelik hayatta ve ev içinde kullanılacağı, tamamen elektriklenmiş modern evleri betimleyen farklı içerikte hazırlanmış dergiler eşlik ediyordu. $\mathrm{Bu}$ dergiler, hane içinin yeniden organizasyonunda elektriğin fiziksel olarak evi nasıl dönüştürdüğü, elektriğin nasıl pazarlandığı ve alımlandığına dair anlatılara yer veriyordu. Bu anlatılar gündelik hayat eksenli Cumhuriyet modernleşmesini anlamamız açısından önemli bir noktada duruyor.

\section{Elektrikli Tenvirat ve Domestik Alanın Rasyonelleştirilmesi Çabaları}

Asri, rasyonelleştirilmiş ev hamlesinde ve muasır insanın bu yeni meskeninde, gündeliğin maddi yönü olan nesnelerin ve eşyanın değişimi kilit bir noktadaydı ve elektrik kullanımı ile fennî tenviratın bu dönüşümde rolü büyüktü. Farklı içerikte hazırlanan Ameli Elektrik, Yedigün, Arkitekt gibi dergilerde Elektrik Şirketi'ne nasıl abone olunacağı, elektrikli ürünlerin nasıl çalıştığı, nasıl verimli bir şekilde kullanılacağı ve işleri nasıl kolaylaştırdığına dair yazılar ve reklamlar yer alıyordu. Orta ve üst sınıf profillerine hitap eden elektrikli eşyalar arasında ütü, süpürge, mini ve büyük fırınlar, ocaklar, su ısıtıcıları, dikiş makineleri, mutfak sobaları, ızgaralar, zayıflama aletleri asri ev ürünleri olarak takdim edilip, halkın bilgisine ve beğenisine sunulmuştu. Daha geniş kesimlerce kullanılabilmeleri için on iki veya yirmi dört ay vadelerle satılıyorlardı. Bu aletler evlere girdiği takdirde hayat kolaylaşacak, evler evcilleşerek şefkat, sevgi ve neşe dolu yuvalar haline gelecekti (Akçura 2001; Delice, 2007).

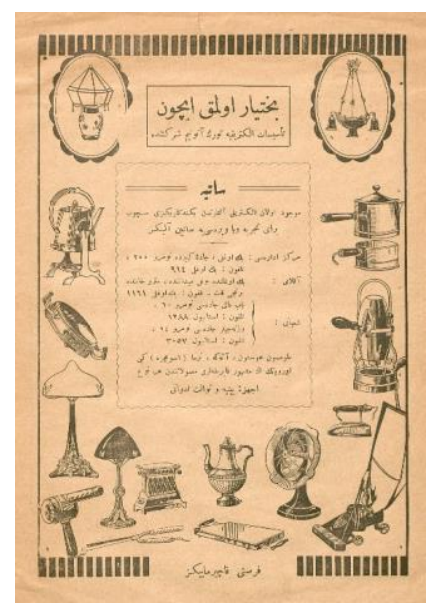

Resim 3. "Bahtiyar olmak içün, Tesisat-ı Elektrikiye Türk Anonim Şirketinde... Satie: Mevcud olan elektrik aletlerinden beğendiklerinizi seçüb bir ay tecrübe veya veresiye satın alınız." (Ameli Elektrik, 1926). 
Elektrik daha önceki enerji kaynaklarından (su ve kömür gibi) farklı olarak, doğada var olan bir enerji kaynağı değildi. Aksine, maddi olmayan bir yapıya sahipti. Görülemiyor, koklanamıyor, tadılamıyor, duyulamıyor, ölümcül sonuçları olmadan dokunulamıyordu. Fabrikalar, kablolar, makineler ve aletler aracııı̆ıyla varlığını bizlere kanıtlıyordu (Gupta, 2015, s. 556-57). Bu garip, henüz tam anlaşılamamış niteliğinden dolayı, elektrik, ilk yıllarda gündelik kullanıcının şüpheyle yaklaştığı bir enerji kaynağı olmuştu. Şebekeye bağlanıp elektrik abonesi olmaya karar verenlerin ise bu teknolojinin avantajları ve tehlikelerine dair ayrıntılı bir biçimde hem Elektrik Şirketi’nce hem de devletin yayın organları aracılığıyla bilgilendirilmeleri gerekiyordu (Gooday, 2008). Emgin Şavk (2014, s. 225) endüstriyel düzeyde elektriğin Türkiye'de ulusal ilerlemenin katalizörü olarak görüldüğünden, teknolojinin dönüştürücü gücüne duyulan teknokratik bir inancı uyandıran makinelerde somutlaştığını, ancak domestik ölçekte elektrik enerjisinin kullanımının endüstriyel düzeyde olduğu gibi doğal ve zaruri bir gereksinim olarak görülmediğini iddia eder. Elektriğin bir enerji kaynağı olarak kullanılmaya başlamasından itibaren, elektrik kaynaklı kazaların günlük basında yer alıyor olmasının bu şüphecilikte rolü olabilir. Özellikle elektrik işlerinde çalışanlar için bu kazalar neredeyse kaçınılmazdı. Bu işte çalışanlar bile elektriğin tehlikelerine maruz kalırken, hane içini elektriklendirmek halk arasında korku ve endişe yaratmış olabilir. Her ne kadar on dokuzuncu yüzyıl sonu ve yirminci yüzyıl başlarında elektrik, popüler imgelemde gizemli, büyüleyici bir etki yaratmış olsa da, bu yeni teknolojinin gündelik hayatta kullanımı problemlerin ve kazaların habercisiydi (Gooday, 2008, s. 122).

Öte yandan erişim güçlükleri ve havagazına kıyasla elektrik tüketiminin daha masraflı olması gibi caydırıcı etmenler, bu yeni teknolojinin hane içine ve gündelik hayata nüfuz etmesini güçleştirmekteydi. Bu bağlamda, evde elektrik kullanımının pazarlanma süreci, bu kullanımın bir "gereksinim" olarak kodlanması çabalarına tanıklık etmişti. Elektrik firmalarının ve lamba markalarının reklamlarında, elektriğin lüks olduğu algısını dönüştürmeye yönelik söylemlere sıkça yer veriliyordu. Alıcı, elektrik aydınlatmasının hayati gerekliliğine, uzun vadede havagazından daha hesaplı olacağına, bazen de elektrik ışığının bu paranın hakkını verdiğine ve yapılan masrafa değdiğine ikna edilmeye çalışılıyordu. Örneğin, elektrikli lamba kullanıldığı takdirde harcanacak olan miktar, ekmek, kibrit, sigara, gazete gibi günlük tüketim ürünleriyle karşılaştırılıyor ve sanıldığının aksine elektrik kullanımının bir lüks olmadığı vurgulanıyordu (Elektrik Tenviratı Pahalı Değildir, 1931).

Bazı reklamlarda ise elektrik aydınlatması rasyonel ihtiyaçları adreslemenin ötesinde bir arzu nesnesi haline geliyor, "asri bir evin kaçınılmaz bir ihtiyacı" olarak sunuluyordu. Üreticinin 
lamba reklamları aracılığıyla gereksinimleri de ürettiği (Lefebvre, 2007, s. 68) ve yeni Türk toplumunun "asri ev" arzusunu biçimlendirdiği bu örneklerde, elektrik ışığı altında huzurla oturup kitap okuyan modern çekirdek aile ya da bir masa etrafında sosyalleşen şık giyimli kadınerkek grupları tasvir ediliyor, bu imajlara "Ziyadan iktisat etme!", "Iyi bir ziya asri bir evin mübrem [vazgeçilmez] ihtiyacıdır" gibi sloganlar eşlik ediyordu (Osram, Ziyadan İktisat Etme!, 1932).

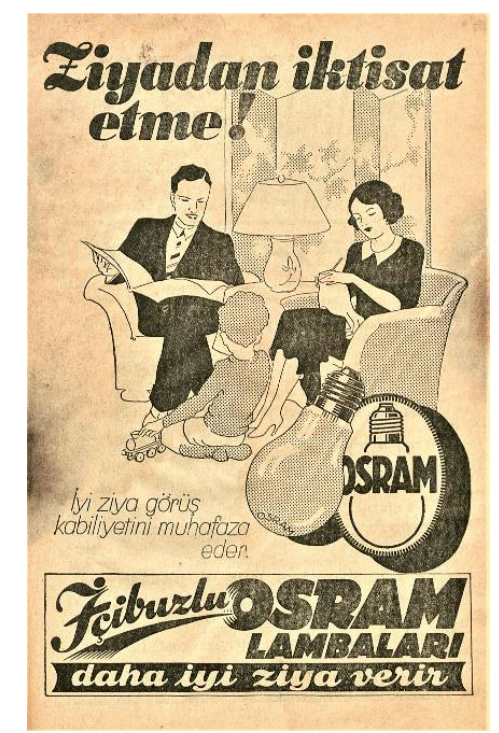

Resim 6. Osram Lambaları reklamı "Ziyadan Iktisat Etme!”, "İyi ziya görüş kabiliyetini muhafaza eder." (Ameli Elektrik, 1932)

Sergiler ve düzenli toplantılar da elektrikli aletlerin tanıtımında önemli hale gelmişti. Bu ürünleri pazarlayan SATiE şirketi, ev kadınları için elektrikli aletleri nasıl kullanılacağının anlatıldığı toplantılar tertip ediyor ve dönemin gazete ve dergileri aracılığıyla kadınları bu toplantılara davet ediyordu.

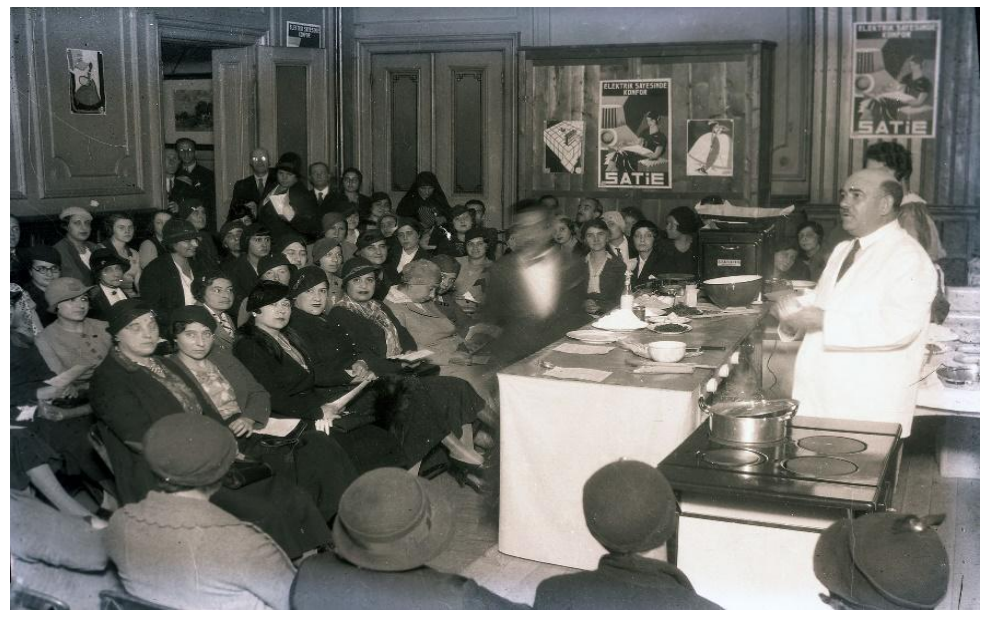

Resim 4. Elektrikli ev aletleri üreten SATIE firmasının tanıtım toplantısı: Aşçı ve toplantıya katılan kadınlar 1930'lar, Suna ve İnan Kıraç Vakfı (SViKV), IAE, CFA_2353 
Bu ürünler sadece gazete veya dergilerde değil vitrinler veya büyük panolarda yer alan reklam ve ilanlarla da potansiyel tüketicilerini arıyordu. Asri evin en önemli öğesi, modern bir aileydi ve bu aile fertlerinin ekonomik, sağıklı, hijyenik ve mutlu bir hayat sürmelerinde elektriğin rolü büyüktü. Bu teknoloji ürünleri, Cumhuriyet rejiminin tahayyül ettiği çağdaş kadın, erkek ve çocuk imgeleri eşliğinde sunuluyor ve rejimin "asrilik" vurgusunu böylelikle pekiştiriyordu (Köse, 2016; Sezgin, 2011, s. 23).

Elektrikli aydınlatma ürünlerinin tanıtılmasında ise cumhuriyet elitinin pozitivist diliyle uyumlu bilimsel ifadeler kullanılıyor, doğru ışığın hane Taylorizmine etkisi vurgulanıyor ya da ürünün verimlilik, hijyen ve sağlık eksenli gerekliliğine dikkat çekiliyordu. Aynı zamanda bireylere mutluluk ve konfor, yaşadıkları mekânlara ferahlık getirecek "medenileştirici" gücünün altı çiziliyordu. SATiE firmasının “ìi bir tenvir elde etmek için” başlıklı yazısında, tüm bu söylemlerin özetini içeren bir liste yer alır. Bu listeye göre iyi bir tenvir; iyi bir göz hıfzıssıhhasının esas şartıdır, fabrikanın randımanını çoğaltır, yazıhane işini kolaylaştırır ve tesri eder, mağazada satışı çoğaltır, eve ferahlık ve konfor verir, sokakta emniyeti temin eder, memurlar ile ameleyi hoşnut eder, sınai ve (yahut) ticari bütün teşkilatın esas unsurudur. İyi bir tenvir elde etmek için ise iyi lambalarla iyi bir tenvir cihazı kullanmalı ve tesisat asri teknik kaidelere göre hesap edilmelidir (İyi Tenvir, 1932, s. 40-41; Akçura, 2001).

Yine "Osram Lambaları" reklamında ise "Evinizi daha iyi tenvir suretile güzelleştiriniz!" sloganı kullanıımış ve iyi bir ışıkla donatılan odanın, insanın hem fiziki hem de psikolojik sağlığına nasıl iyi geleceğine dikkat çekilmişti. Aynı zamanda elektrik ziyasında tasarruf yapılmaması gerektiği vurgulanmıştı.

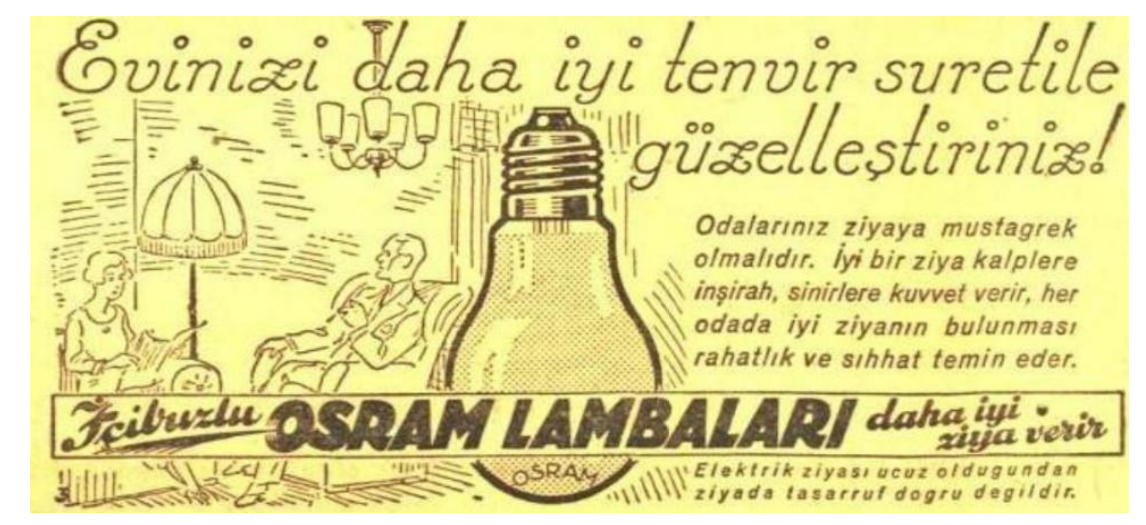

Resim 5. Osram Lambaları reklamı, “Evinizi daha iyi tenvir suretile güzelleştiriniz!” (Cumhuriyet, 1930).

Bu "Osram Lambaları" örneğinde olduğu gibi ev içi tenviratın iç içe geçen birçok faydası güzellik, sıhhat, konfor, ölçülülük- bir arada belirtilebildiği gibi, reklamlar aydınlatma vesilesiyle 
ortaya çıkabilecek tek bir işlev veya faydayı da ön plana çıkarabiliyordu. Dolayısıyla, Türkiye'de de dünyanın birçok yerinde olduğu gibi elektriğin modern kimliğinin, bu yeni teknoloji ile ilgili korku ve endişeleri bertaraf edecek ve onu daha cazip hale getirecek biçimde kurgulandığını söyleyebiliriz (Gooday, 2008, s. 122; Nye, 1990). Bu kurguyu, yeni ulus-devletin asri ev tartışmaları ile uyum içinde, bilimsellik, sağıı, tasarım ve işlev vurgularının yer aldığı örnekler tamamlar.

Fennî tenvirat: Güzellik meskeninden verimlilik mekânına

Modern gündelik hayat, her şeyin hesaplandığı, değerlerin para ve zaman gibi birimlerle sayısallaştığı ve hatta bireylerin de bu matematiksel sistemin bir parçasına dönüştüğü bir alan olmuştur (Lefebvre, 2007, s. 32). Buna bağlı olarak yirminci yüzyılda ev, manevi refah kaynağı olan bir "güzellik" meskeninden, fiziksel donanımıyla öne çıkan bir "verimlilik" mekânına evrilmişti (Forty, 1986, s. 108). Bu dönüşüm, erken cumhuriyet Türkiyesi'nde Kız Enstitüleri'nin eğitim anlayışına da yansımıştı. Bu kurumlarda yöneticilik ve öğretmenlik yapan kadınlar, ev kadını için "evini maddeten ve dolayisile manen mes'ud edebilmesi için bilinmesi lazım gelen fennî bilgiler" sunan kılavuzlar yayımlamaya başladı (akt. Navaro-Yaşın, 2000, s. 58). vii Bu girişimler, henüz biçimlenmekte olan "asri ev" tahayyülünün düzenli, sistemli ve verimli bir üretim alanı olarak şekillenmesinde etkili oldular. Tenvirat da "Taylorize" edilmesi gereken unsurlar arasında yer alıyordu. 1936'da Süheyla Altunç, enstitülerin ev ekonomisi derslerinde okutulan Ev Idaresi kitabının "Tenvir" başlıklı bölümünde, petrol lambasının gündelik temizliğinde yapılması gerekeni detaylı biçimde tarif etmişti. Oysa Altunç’a göre "hararet neşretmeyen, su buharı hâsıl etmeyen" elektrik lambasının bakımı çok daha kolaydı (Altunç, 1936, ss. 51-53). Ameli Elektrik'te ise, tozlanma nedeniyle elektrik lambasının veriminin bir ay sonunda yüzde beş ile yirmi arasında düştüğü ve bunun önlenmesi için lambanın muntazaman tozdan temizlenmesi gerektiği anlatılmıştı (Tenvir Daimî Tenviratı, 1934). Buna ek olarak, lambalar sekiz yüz ila bin saat yandıktan sonra eskimeleri nedeniyle değiştirilmeliydi (Bir Kaç Tavsiye, 1931).

Verimlilik tartışmaları ve bahsedilen uygulamalar doğrultusunda orta gelirli Türk hanelerine girmeye başlayan "düzen", "rasyonalite" ve "disiplin" düşünceleri, ev kadınının işlerini belirlenmiş zaman tarifelerine oturtuyordu (Navaro-Yaşın, 2000). Elektrik aydınlatması sayesinde ise, önceleri güneşin doğuş ve batış vakitlerine göre ayarlanan işler artık günün her 
saati yapılabilecekti. Üstelik güçlü ve homojen elektrik ışığı bu işlerin yapılışını da optimize edecekti. Örneğin, mutfak, "akşamları ekseriya geç vakitlere kadar çalışılan” bir yer olarak tanımlanıyordu (Mutfak, 1931). Bu, 1931 tarihli bir lamba reklamında şu ifadelerle açıklanmıştı:

Mutfağını daha iyi tenvir et! Çalışdığınız yer ayrıca bir lamba ile tenvir edildiği taktirde iş daha iyi ve daha çabuk görülür. Yemeğin pişmesi bu suretle daha iyi takip edilir. Bunun için her ev kadını mutfağının daha iyi tenvirine çalışmalıdır. İçi buzlu Osram lambaları daha iyi ziya verir (Osram, Mutfağını daha iyi tenvir et!, 1931).

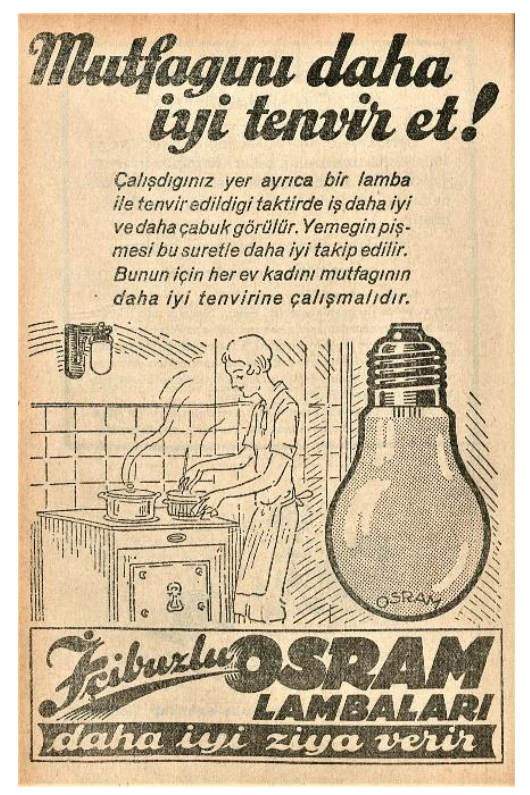

Resim 7. Osram Lambaları reklamı. “Mutfağını daha iyi tenvir et!” (Ameli Elektrik, 1931)

Evdeki elektrik tenviratı hem kadının evdeki işlerini yaptığı zaman çizelgesine, hem de bu işlerin yapılışına etki edecek bir unsur olarak sunuluyordu. Pek çok lamba reklamında ev kadını, akşam vakti ütü yapmak, dikiş dikmek gibi gündüzden kalan ev işlerini elektrik lambasının ışığı altında gerçekleştirirken resmediliyordu. Öte yandan, ilerleyen bölümlerde değineceğimiz üzere asri ev aynı zamanda çalışarak ülke ekonomisine katkı sunan yeni adam için bir istirahat yuvası olarak da tanımlanmaktaydı. Abajurlardan sızan tatlı endirekt ışık ile evin erkeğine dinlendirici bir atmosfer sunacağı vurgulanan elektrik aydınlatması, bir yandan da güçlü ve homojen ışığıyla kadının düzgün dikiş dikebilmesini, daha hızlı yemek yapabilmesini olanaklı kılarak kadının fiziksel çevresini bir fabrikaya dönüştüren bir mekânsal bileşen olarak tanımlanmıştı. Dolayısıyla, ev ekonomisi ve ev işlerindeki verimliliği artırma üzerine yapılan çalışmaların muhatabı ve sorumlusu ev kadınıydı. Türkiye'deki ev kadınlarının ev işlerindeki verimliliğinin artırılmasındaki amaç, Avrupalı hemcinsleri gibi çalışma hayatındaki katılımlarını artırabilmek değil, evin içinde daha üretken bir kadın, daha ilgili bir anne ve eş olabilmelerini sağlamaktı. Bu bağlamda kadının 
hane içindeki görevlerini optimize etmek, "asri ev" kurgusunu sağlayabilmek için gerekliydi. Bozdoğan'ın ifadeleriyle bu ev, "temizliği, estetiği ve konforu ile hayat mücadelesinden eve dönen erkeği huzura kavuşturup yeniden üretecek bir "sığınak"; kadının becerileri ve tutumluluğu ile sade ve kullanışlı olarak düzenlenmiş bir "aile yuvası"ydı" (Bozdoğan, 1998). Böylelikle elektrikli lamba tanıtımları da kadının iyi bir anne ve eş olarak klasik görevlerini yerine getirdiği, babanın ise bu konforlu ve huzurlu ev ortamından faydalandığı bir anlatıyı destekleyen ve toplumsal cinsiyet rollerini yeniden üreten araçlara dönüşmüştü.

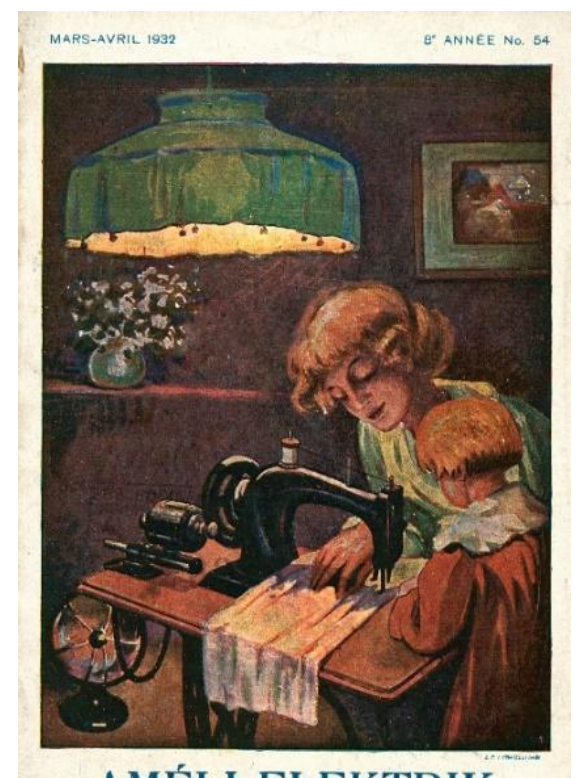

\section{AMÉLI ELEKTRIK}

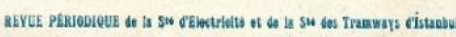

Resim 8. Ameli Elektrik dergi kapağı, Mart-Nisan 1932

22 Ekim 1936 tarihli Cumhuriyet gazetesinde yayımlanan Luma lamba reklamında, ürünün "dünyanın en namdar üniversitelerinin en otoriter fen enstitüleri" tarafından tasdikli olduğu belirtilmişti. Yedigün dergisinde, ${ }^{1937}$ 'de lamba üreticisi Osram tarafından verilen "tenvirat reçetesi" başlıklı reklamlar serisi yayımlandı. Her biri diğerinden farklı olan bu "reçete"lerde, yüksek masada yemek yiyen aile, modern mutfakta çalışan kadın gibi imajlarla beraber verimlilik hesabı, Dekalumen verileri, çift spiralli lambalar gibi fazlasıyla teknik ifadeler yer alıyordu (Osram, Tenvirat Reçetesi no.5, 1937) (Osram, Tenvirat Reçetesi no.7, 1937). "Reçete" metaforunu kullanarak tıbbın evrensel ve bilimsel geçerliliğine referansla elektrik aydınlatması, bir anlamda da maddesiz halinden sıyrılıp tanımlanabilen ve ölçülebilen bir hale bürünüyordu. Modern kullanıcı ise, bu reçete aracılığıyla ev içindeki diğer pek çok şeyi olduğu gibi ışığı da hesaplamakla mesul tutuluyordu. Yeni toplumun yeni ferdi, domestik alanda da zamanın ve 
paranın kıymetini bilen, yeri geldiğinde tasarruf edip yeri geldiğinde harcayabilen, bilimsel bilgiler ışığında hesabını yapabilen bir vatandaş olarak resmediliyordu.
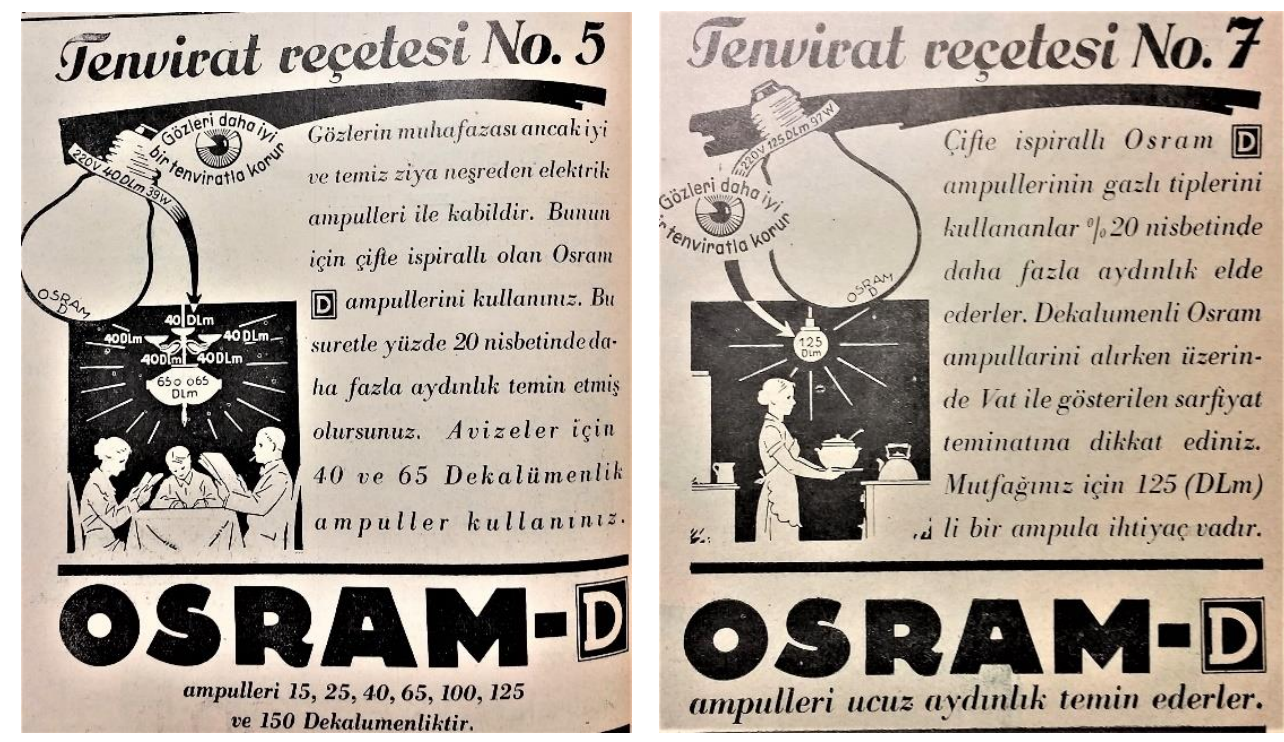

Resim 9. Osram Lambaları reklamları. "Tenvirat Reçetesi” (Yedigün, 1937, no. 207 ve no. 209).

Rutubetsiz, kokusuz, güneşli, havalı, gecesi gündüz, gündüzü gece olabilen bir ev

"Asri ev" tartışmalarında görüş bildirenlerin üzerinde uzlaştığı en temel nokta, ev içi mekânının ev halkı için sağııkı ve hijyenik bir ortam sunması gerektiğiydi. Türkiye'de kamu sağ|ığı tartışmaları ve temiz mesken vurgusu, özellikle 1920'li yıllardan beri çeşitli mecralarda yaygın biçimde tartışımaktaydı. 1929'da Cumhuriyet gazetesinde yayınlanan bir yazıda, Dr. Reşit Galip "sıhhatimiz yanlız bizim değil ayni zamanda milletin malidir. Onu korumak milli vazifelerdendir" diye yazmıştı (Galip, 1929). Sağlıklı olmanın milli bir vazife sayıldığı bu dönemde ev kadınından aile üyelerinin, özellikle de çocuğun sağlığını ve refahını temin edebilmek için evini hijyen kurallarına uygun biçimde tanzim etmesi bekleniyor, popüler dergilerde temizlikle ilgili ipuçları veriliyor, dekorasyon köşelerinde toz tutmayacak, sade ama sıhhi eşyalar öneriliyordu.

Öte yandan, asri ev kurgusunda öne çıkan sağlık ve hijyen kaygıları ile ilişkili bir “Havadar ve bol güneş alan ev" ifadesi, dönemin gerek popüler yazınında gerek modern mimarlık tartışmalarında konut için en temel kabullerden biri olmuştu. Karanlık, tozlu ve rutubetli ortamların özellikle verem gibi hastalıklara yol açtığı kabulüyle beraber evlerin bol güneşli, bol ışıklı olması bekleniyordu. Yedigün'de (1934) yayımlanan "Güneşin Saltanatı” başlıklı yazıda, eskiden mehtabın hüküm sürdüğü, yağ kandilli karanlık odalar; uçuk benizli ve hastalıklı insanların melankolik şiiriyle özdeşleştiriliyor, artık, her tarafı camlı binalarda güneşin 
saltanatının başlangıcı müjdeleniyordu (Fevzi, 1934). Aynı derginin bir başka nüshasında, "Bol güneşli bir yuva" başlı̆̆ı altında bol ışık ve bol hava esasına göre yapılmış bahçeli, küçük bir asri ev betimleniyordu (Bol Güneşli Bir Yuva, 1933). Bu yaklaşım, elektrik tenviratının, evin her kısmına nüfuz etmesi istenen gün ışığının gücünü ve kalitesini ikame etmekle görevlendirilmesine yol açtı. Lamba reklamlarında olduğu gibi, popüler yazında yer alan ideal ev tasvirlerinde de, güneş battıktan sonra elektrik aydınlatmasının hükmü başlıyordu. Hakimiyet-i Milliye' de yayımlanan "Eski Ev, Yeni Ev" başlıklı yazıda, 1930'ların modern meskenleri, tarih öncesi devirlerde mağarada yaşayan insanların koşullarıyla karşılaştırılmıştı (Eski Ev, Yeni Ev, 1930). Buna göre, güneş battıktan sonra çaresizlik ve korkuyla kaplanan ilkel evlerin yerini artık, "rutubetsiz, kokusuz, güneşli, havalı, gecesi gündüz, gündüzü gece olabilen bir ev" almıştı.

Ev hijyeni için de gerekli görülen elektrik aydınlatmasının avantajları arasında, gaz ve yağ lambalarına nazaran çok daha "temiz" bir kaynak olması gösteriliyor, "fena kokular neşreden, etrafta bulunan eşyayı kirleten, tavan ve perdeleri karartan" petrol lambasından çok daha üstün olduğu vurgulanıyordu (Tenvirat, 1930). Ev Idaresi kitabında Altunç (1936), kullanım rahatlığı, göz sağlığı ve hijyen kriterlerine göre ele aldığı aydınlatma kaynaklarını, iyiden kötüye "elektrik, asetilen, gaz, mum" biçiminde sıralamıştı. Son olarak, evin tümünü güçlü bir biçimde aydınlatacak elektrik ışığının toz ve kirleri görünür kılacağına çokça vurgu yapılıyordu. Ameli Elektrik'te yayımlanan "Mutfakta Elektrik Ziyası" başıklı yazı, "Aynı zamanda unutmamalıdır ki temizlik için ziya lazımdır ve ancak temiz bir mutfaktan sıhhî yemekler çıkar" ifadeleriyle sonlandırılarak, iyi bir aydınlatmanın mutfak hijyeni için önemini vurguluyordu (Mutfakta Elektrik Ziyası, 1932).

Elektrik aydınlatmasının kamusal ve özel alanda kullanımının yaygınlaşması, iyi tenvirin nasıl yapılması ve göz hastalıklarından kaçınmak için ışığın nasıl kullanılması gerektiğine dair teknik tartışmaları da beraberinde getirmişti. "Ziya ve Rüyet" (Işık ve Görme) adlı bir yazıda göz ve ışık arasındaki ilişki şu şekilde açıklanıyordu:

Göz için en musait şerait çok miktarda ziyanın bilcümle eşyayı bol bol aydınlatması ve onların hareketsiz ve zahmetsiz görünebilmesidir. Sun'i ziya bol olmalı ve gayede bittabi günün ziyasına benzemesi bulunmalıdır. Ziyanın ademi kifayesi, göz vazifesini ifa etmek için nisbetsiz derecede mesai sarfına mecbur olacağından, kuvvei basırayı it’ap eder. Bilakis bol, tatlı ve makul surette derece derece artan ziya, büyük bir zevk ve hazzı mucip olur. Bu adeta hayatı beşer müddeti mukadderesini temdid demektir (Ziya ve Rüyet, 1929). 
Göz sağ|ığı konusunda yapılan başlıca vurgu, yetersiz aydınlatmanın miyop olmaya neden olacağı ya da bilinçsiz kullanımın kamaşmaya yol açarak rahatsızlık vereceği üzerineydi. Evin farklı mekânlarında ne tür ışık kullanılması, kullanılacak olan ışığın hangi açıyla gelmesi gerektiği ve teknik içerikleri ayrıntılı bir biçimde anlatılmıştı. "Fena tenvirin gözleri fazlasıyla yorduğu," fakat görüş kabiliyetini muhafaza eden “iyi ziya”nın hayattan zevk ve haz almayı sağladığı belirtilmişti (İyi bir tenvir, 1932; Gözlerinizi koruyun, 1932, Ziyadan iktisat etme, 1932). Yeni rejimin yapı taşı olarak sunulan ailenin sağlıklı bireylerden oluşması önemliydi, dolayısıyla elektrik ışı̆̆ının sıhhat ve hijyen açısından en faydalı şekilde kullanımı, ulusal modernleşme bağlamında modern evin rasyonellik ve verimlilik gibi bilimsel gereksinimlerini tamamlayıcı bir unsur olarak görülüyordu.

Hakiki konfor, ambiyans ve değişen işlevler

Görüş kabiliyetini iyileştirme ve görsel konforu sağlamanın şüphesiz ki göz sağlığını temin etme ötesinde de faydaları vardı. Evin içindeki aydınlatma tercihlerinin insanı rahatlatma ve dinlendirme gibi etkileri olduğu bilinmekteydi ve modern insan için ideal ev aynı zamanda bir "istirahat yuvası" niteliğini taşımalıydı. Adrian Forty’nin (1995) açıkladığı gibi endüstri devriminden etkilenen toplumlarda, ağır koşullarda çalışan birey evi ile işyeri arasında keskin bir ayrım yaratma eğiliminde olmuştur. Endüstrileşme öncesinde ev ile işyerinin sınırları daha muğlaktı, örneğin çiftçi ya da zanaatçı için ikisi çoğunlukla aynı yerdi. Ancak fabrikada, ofislerde yorucu bir tempoda çalışan kişi evinin fiziken ve manen başka bir dünya olmasını istiyordu. Her ne kadar Türkiye'deki durum Batı medeniyetinin endüstrileşme eksenli modernitesinden farklı olsa da, toplumun deneyimlediği dönüşüm sürecinde de modern eve benzer anlamlar yüklenmekteydi. Cumhuriyetin erken döneminde bu ayrıma dikkat çekiliyor, asri ev bir “istirahat yuvası” olarak tanımlanıyordu. Baltacıoğlu, 1929'da bunu şöyle özetliyordu:

Konfor fikri hiç bir devirde bu kadar ilerlememiştir. Binaenaleyh insanı eyi, sağlam ve güzel olarak muhafaza edemiyen kaplar muasır aletler olmazlar. Bütün bu konforun hedefi insanın maddi ve manevi saadeti olduğundan binaların ve onun parçalarının insan vücudunu ve insan ruhunu konforlu bir zarf gibi taşıması lazım gelecektir. Esasen bu fikir sihhat fikrinin bir yüzüdür. Şu taktirce muasır adam için ev ne bir ibadethane, ne bir istihsal ne de bir tahsil ve terbiye muhitidir, sadece istirahat yeridir. Muasır adamın ali hayatını taşıyan kaplar hep bu şartları haiz olmalıdır. Aksihal muasır zihniyetin temelini sarsar (Baltacıoğlu, 1929, s. 119). 
Tasarım disiplini ise, rahatsızlık ve anksiyeteden arınmış bir gelecek tahayyülünde bilim ve teknolojinin imgelerini kullanacak (Forty, 1995, s. 206) ve bu konforlu ve huzurlu istirahat yuvasının tanziminde önemli rol oynayacaktı. Eşyanın sosyal psikolojideki rolünü araştırdığı çalışmasında Nuri Bilgin, evin ambiyans ya da atmosferinin oluşmasında ışıklandırmanın belirleyici olduğunu ifade eder. Aydınlatma araçlarının seçim ve kullanımında ambiyans faktörünün gözetilmesi de, modern aile gruplarına özgü bir durumdur (Bilgin, 2011, s. 214). Işık kaynağının çıplak bırakılmayarak abajur ile kapatılması, homojen ışık yayan buzlu lamba kullanımı, tavanlardaki gizli ışık detayları, tek bir kaynaktan güçlü ışıklandırma yapmak yerine aydınlatma araçlarının çeşitlendirilip çoğaltılması gibi kararlar, mekânda ışık sayesinde "dinlendirici" bir atmosfer yaratmayı olanaklı kılmaktaydı. Hane içi modernleşme çabalarında, bu kriterlerin göz önünde bulundurulmaya başlandığını görürüz. Örneğin, bir lamba reklamında, "Ziyadan tasarruf yanlış tasarrufdur" vurgusu yapılıyor ve "Daha iyi ziya fena ziyadan pek cüzi pahalıdır, fakat buna mukabil hayata daha fazla istirahat ve inşirah [iç rahatlığı, gönül açıklığı] verir. İyi tenvir edilen bir ev neşe ve rahatlık membaı demekdir." denilerek elektrik aydınlatmasının evin konforuyla ilişkisine dikkat çekiliyordu (Osram, Ziyadan tasarruf yanlış tasarrufdur, 1931). Kısacası, modern bir evde aydınlatmanın rolü yalnızca birincil işlevi olan görme eylemini sağlamak değildi. Ambiyans kriterleri gözetilerek tanzim edilen bir konutta modern bireyler kendi köşelerine çekilebilir, yarı mahrem alanlarında kitap okuyabilir ve dinlenebilirlerdi (Bilgin, 2011, s. 241).

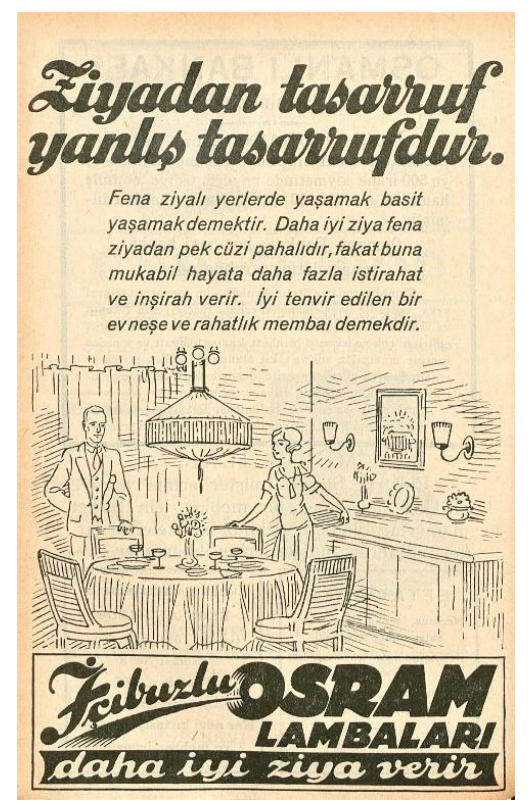

Resim 10. Osram Lambaları reklamı. "Ziyadan tasarruf yanlış tasarrufdur."(Ameli Elektrik, 1931) 
Elektrik tenviratının evde konfor yaratmadaki bu rolü, asri konut tartışmalarında aktif biçimde yer alan dönemin mimarlarının da dikkatini çekmişti. Mimarlıktaki modernleşmenin aktivistlerinden Mimar Behçet Ünsal, 1939'da yaptığı bir radyo konuşmasında şu ifadelere yer veriyordu: "Modern mimarlığın vasfı insanları otomatik ve mekanik asrımız hayatının sinirlerimizi yoran ve ruhlarımızı bozan günlük meşguliyetlerimizden sonra hakikî konfor ve estetik ile bizleri dinlendirebilmesi, tatmin etmesi hattâ tedavi edebilecek şekilleri haiz olmasıdır." (Ünsal, 1939). Ünsal, ideal bir evi betimlerken konforun önemine ve bu konforu sağlamakta mimarlığın ve ışığın rolüne şu şekilde dikkat çekiyordu:

(...) Sokağın gürültüsünden uzak ve bir sağlık müessesesine girer gibi her tarafınızı sükûnet ve rahatlık kaplıyaraktan böyle bir meskene girerseniz. Daha içerlerini görmek sabırsızlığı bu girişin üzerinizde bıraktığı ilk tesirdir.(...) Lâkin bu salon ne ferah.. Fakat bu raflar bu dolaplar şu ışık tertibatı bu şömine herşey yerli (gömme, sabit)(...) işte hakiki konfor.. Bu konfor öyle kuru ve hissiz değildir. Konforla beraber en güzel şekiller de aranılmış, bulunmuş ve tatbik edilmiştir. Velhasıl yapının içi, dışı her şeyinde bir güzellik, güneş, sıcaklık, kolaylık, rahatlık, kullanış ve huzur var. Renk armonileri, renkli camlardan süzülen ışıkların gönül alan şeffaflığı, sabit mobilyalar, duvardaki fereskli gizli ışılar ve bunların renkler üzerindeki refleleri. Oh burası işte tam bir güzellik ve saadet yuvasıdır. Tam bir istirahat ve yaşama yeri... Devrimizin modern mimarlığı san'at tarihine mesken mimarlığı diye geçecektir. Mimarın eseri bir lüks bir süs değildir. Ruh ve sıhhat üzerinde, hayat üzerinde, kültür ve terbiye üzerinde Mimarlık eserlerinin ne tesirler yaptığını böyle hakikî mimarlık eseri olan yuvalarda yaşıyanlardan sorunuz (Ünsal, 1939, s. 60-62).

Ünsal gibi Arkitekt’te modernleşme üzerine yazan dönemin mimarlarının da farkında olduğu üzere, modern mimarlık düşüncesiyle beraber konut iç mekânı işlevsel olduğu kadar ruhu da olan, her unsuru birbiriyle ilişkili bütüncül bir mekân anlamını kazanmıştı. Modern mimarlık düşüncesine göre yapılar içeriden dışarıya doğru olduğunca geçirgen biçimde tasarlanıyor, hacimler tıpkı bir makinenin parçaları gibi birbirine eklemleniyordu. Bu yeni mekânsal kurgunun işleyebilmesi için elbette yeni unsurlar gerekliydi. Artık sofalı, kafes pencereli, kargir Türk evinin yerine, oturma, çalışma, yemek, yatak odaları ayrılmış, işlevlerine uygun hareketli mobilyalarla döşenmiş betonarme konutlar inşa edilmeye başlanmıştı. Önceden yüklükten çıkarılıp serilen yer yatağı ve yemek vaktinde kurulup kaldırılan yer sofrası ailenin ortak yaşama mekânını farklı zamanlarda farklı işlevlerle dönüştürürken, artık bu işlevler için ayrı odalar, ya da açık planlı 
salonlarda ayrı köşeler tanımlanmaktaydı. Bu alanlarda birbiriyle ilişkili eşya grupları oluşmakta, bu gruplar modern rutinlerin maddi yönünü temsil etmekteydi. Nuri Bilgin'in de ifade ettiği gibi, eşyaların birbiriyle ilişkili olarak gruplanması ve daha büyük sistemlerle, bazen de altyapıyla bağımlı hale gelmesi, modern günlük hayatta eşyaya bağlıı̆ın artması ile neticelenir (Bilgin, 2011, s. 250). Atilla Yücel de, hane içine giren yeni tarz ve tekniklerle beraber gündelik rutinlerin zaman ve mekâna bağımlılı̆ının değişmesini konut modernleşmesiyle ilişkilendirir (Yücel, 1996). Elektrik aydınlatmasının konut içindeki kullanımının, evlerin içindeki mekân organizasyonunun ve tefrişatın geçirdiği bu dönüşüm ile fiziksel çevrede somutlaşan ilişkiler kurduğu görülür. Buna göre, çalışma masası için masa lambası, okuma koltuğunun üzerine ayaklı lamba, yemek masasının üzerine kamaşma yapmayacak biçimde konumlandırılmış bir sarkıt lamba gelmeliydi. Örneğin Ameli Elektrik’te yayımlanan "ìi Tenvir" başlıklı kılavuzda, evde bulunması gereken makyaj aynası, şömine, çamaşırhane gibi hacimler resmedilmiş ve buralar için duvar apliği, avize, masa lambası gibi uygun aydınlatma araçları ve bunlarda tercih edilmesi gereken lamba güçleri betimlenmişti (İyi Tenvir, 1929). Böylelikle evin mekânsal ölçekte katı bir unsuru haline gelen elektrik tenviratı gündelik hayatın işleriyle bütünleşecek, insanların her gittiği yerde arayacağı zorunlu bir özellik haline gelecekti (Terakki İçin, 1932).

Güneş battıktan sonra, artık geleneksel konutta olduğu gibi gün içinde işlev değiştirmeyen mekânlar, buralarda sabit ve tanımlı aydınlatma uygulamaları yapılmasını olanaklı kılıyordu. Dolayısı ile aydınlatma artık mimari bir unsura dönüşmekteydi. İnşa edilmek üzere planlanan bir konut, tefriş şemasıyla birlikte ele alınabiliyor buna bağlı olarak örneğin yemek masasının geleceği alanın üzerine tavan lambası çıkışı, oturma alanının yakınında lambader kullanımına olanak tanıyacak prizler yerleştiriliyor, maddi imkânları yüksek işverenlerin konutları için ise tavanlarda gizli ışık detayları oluşturuluyordu. Öte yandan elektrik aydınlatması, Batı eksenli modern mimarlık söyleminin de önemli bir unsuru haline gelmişti. Bu anlayışa göre konut tasarlayan mimarlar, mobilya ve aydınlatma gibi mekânın tüm unsurlarını bir bütün olarak ele almaktaydı. Modern mimarlık kuramının kurucularından kabul edilen ve mimarlığın toplumları modernleştirmede en önemli araç olduğunu savunan Le Corbusier, gün ışığının performansını yakalayabilmek için gizli ışık detaylarının kullanımına ve endirekt aydınlatmanın gerekliliğine dikkat çekmişti (Le Corbusier, 1986, s. 119).

Yeni mimarlığın elektrik ışığından beklediği, mum ya da gaz lambasının ışığını değil, insan yaşamının en büyük enerji kaynağı olan güneş ışığını ikame etmesiydi. Bu beklenti, modern insanın sıhhati için güneş ışığına verdiği önem kadar, kendi ürettiği çağdaş tekniklere duyduğu 
inanç ve hayranlığın da bir sembolü olarak görülebilir. Bu inanç ve hayranlığa sahip dönemin mimarları ise, inşa edilmiş yapılarını tanıttıkları yayınlarda gece dışarıdan çekilmiş bina imajlarına yer vererek, aslında yalnızca bir strüktür değil, adeta zamanın ruhunun gereği olan modern bir hayatı inşa ettiklerini vurguluyorlardı. Elektrik ışığının bu güçlü iddiasını çeşitli reklamlarda, güneş ışığı batınca onun yerini alan, "güneş gibi aydınlatan" lamba vurgularında gözlemlemek de mümkün.

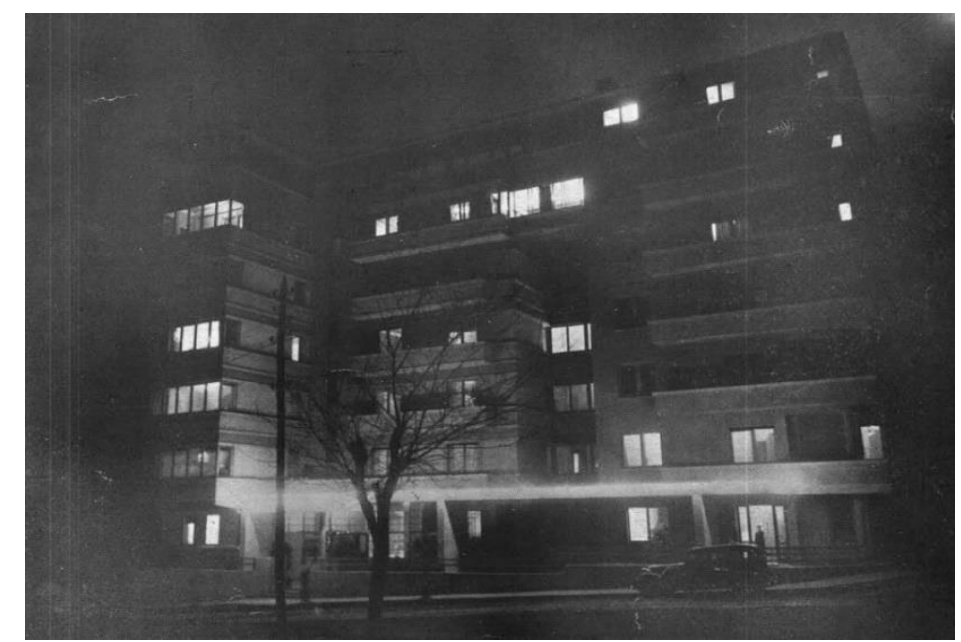

Resim 11. "Kira evi”, proje tanııım yazııından yapının girişi ve gece görünüşü. (Kira Evi, 1935)

Bir başka konu da, mimar elinden çıkmış konutların bazen özel tasarlanmış aydınlatma ürünleri barındırabilmesiydi. Mesleki hayatında medenileştiricilik misyonu edinmiş profesyonel mimarlar, eşyaya büyük önem veriyor ve bu da doğal olarak bütüncül bir sanat yaklaşımının benimsenmesini gerektiriyordu (Turan, 2009, s. 117). Bu yaklaşımdan özellikle Türk modern mimarlığının belirleyici figürlerinden Seyfi Arkan’ın çokça etkilendiği görülür. Bu durum, Arkan’ın dönemi için modern ikonlar haline gelmiş Ankara'daki Hariciye ve Atadan Köşkleri, İstanbul Gümüşsuyu’nda bulunan Kira Evi (Üçler Apartmanı) ve özellikle Florya Atatürk Köşkü’nde açıkça örneklenmiştir. Arkan bu yapılarında, gizli ışıklı aydınlatma detaylarına ve yerli metal atölyelerinde özel olarak üretilmek üzere tasarladığı armatürlere yer vermişti. Örneğin toplumun elit tabakasına yönelik, dönemi için yüksek bir bütçeyle inşa edildiği anlaşılan "Kira Evi” projesi için Arkan’ın kendi tasarımı olduğu düşünülen nikel tavan lambaları üretilmiş, mimar da bu lambanın fotoğrafını özel olarak projenin tanıtım metnine dâhil etmişti (Kira Evi, 1935). Görüldüğü üzere asri ev tartışmalarında gerek yazdıklarıyla gerekse üretimiyle rol alan mimarlar, elektrik aydınlatmasını bir tasarım parametresi olarak bu eve dâhil etmeye özen gösteriyordu. 


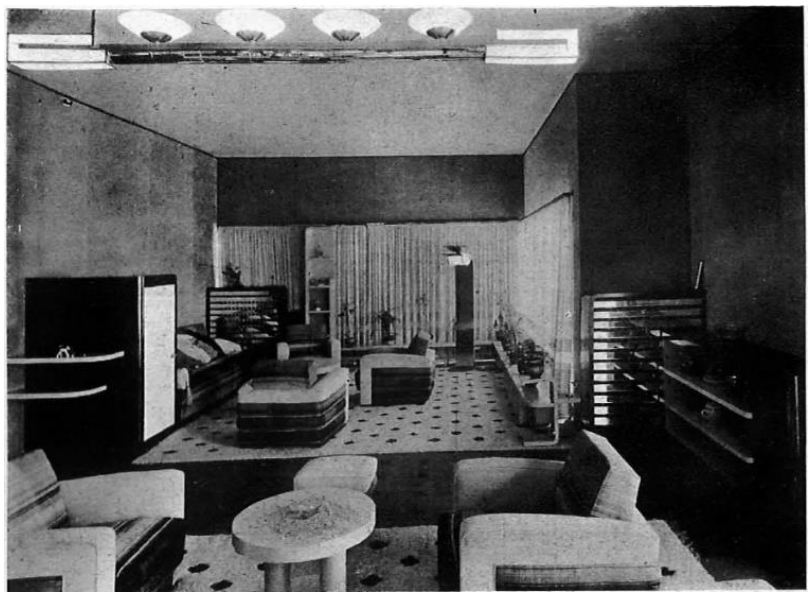

Resim 12. Seyfi Arkan’ın kendi tasarladığı düşünülen aydınlatma elemanı, “Bayan odası” (Arkan, 1936)

Rasyonel içeriğiyle öne çıkan "asri ev", bu içeriğin estetize edilmesiyle tamamlanacaktı. Ameli Elektrik'te tam sayfa yer alan SATiE reklamı, "evinizi ziya ile güzelleştiriniz" diyordu (Evinizi ziya ile güzelleştiriniz, 1931). Bu duyarlılığı örnekler biçimde, elektrik mühendisi Hasan Halet Arkitekt dergisinde yayımlanan "Evlerin Elektrik Tertibatı" başlıklı yazısında mimarlara "Lamba abajurlarını mobilyaya, odanın dahilî tezyinatına ve binanın mimarî tarzına tabi olarak intihap etmelerini" öneriyor ve şu ifadelere yer veriyordu:

Bu kudreti mükemmel vasıtalarla güzel idare ve tatbik etmek asri bir elektrik mühendisinin vazifesidir. Mühendis ekseriya ayni avizeden bir kaç türlü ziya tesirleri elde eder. Vermek istediği güzel neticeleri elde edebilmek için mühendisi lüzumu olan masraftan menetmemelidir. Çünkü pek çok para sarfedilen dahilî oymaları, halıları, örtüleri ve duvar tezyinatını bütün güzeliğile ev sahibine ve misafirlerine gösterecek ve onlara azamî zevki verecek yalnız tenvirattır. (Işıkınar, 1931)

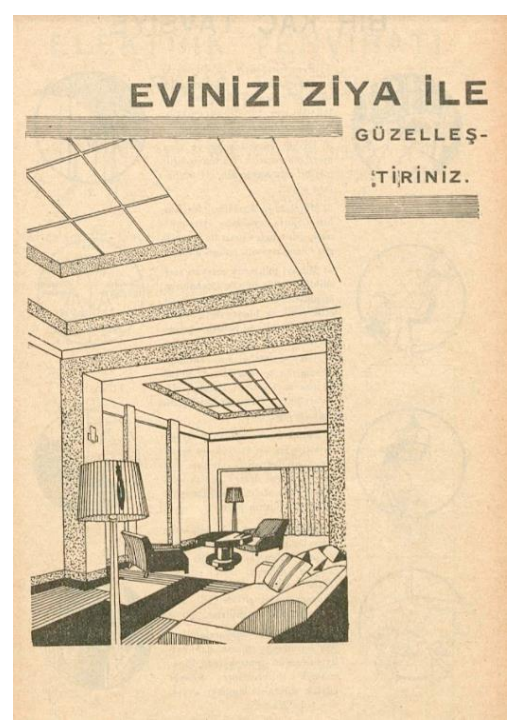

Resim 13. SATiE reklamı, “Evinizi ziya ile güzelleştiriniz.” (Ameli Elektrik, 1931) 
Elektrik aydınlatmasının hane içindeki maddi dünyayı modernleştirmedeki rolü, biçimsel bir kaygıdan çok işlevsel bir anlam barındırıyordu. Tenviratın, evin estetik değerindeki rolü bile, sağladığı ışı̆ıı biçim ve kalitesi sayesinde görünür hale gelecek dekoratif bileşenlerle ilgiliydi. Tasarım yazınında aydınlatma elemanlarının tarz ve görüntüsüyle ilgili ifadelere rastlamak güçtü. Uygulamada ise, modern mimarlık prensiplerini izleyen betonarme bir konutun içinde, klasik tarzda işlemeli bir avize ile modern, geometrik ve yalın çizgilere sahip Art Deco tarzında bir tavan lambası aynı ev mekânında kullanılabiliyordu. Buna benzer biçimde mum, kandil, gaz lambası gibi geleneksel araçlar da uzun yıllar elektrikli armatürlerle beraber kullanılacaktı. Elektrik aydınlatmasının hane içinde dönüşen yaşantıyı sembolize etmekteki ve gündelik hayata hizmet etmekteki rolü biçimsel kaygıların, zeminsiz Batılılaşma çabalarının ötesinde, organik bir medenileşme sürecini belgeliyordu. Bununla ilişkili olarak görülüyor ki, asrilik söylemiyle beraber ev içindeki kurguyu dönüştürmekte olan teknolojik ve rasyonel unsurların, mekânın estetik içeriğine müdahale etmek gibi bir rolü bulunmuyordu.

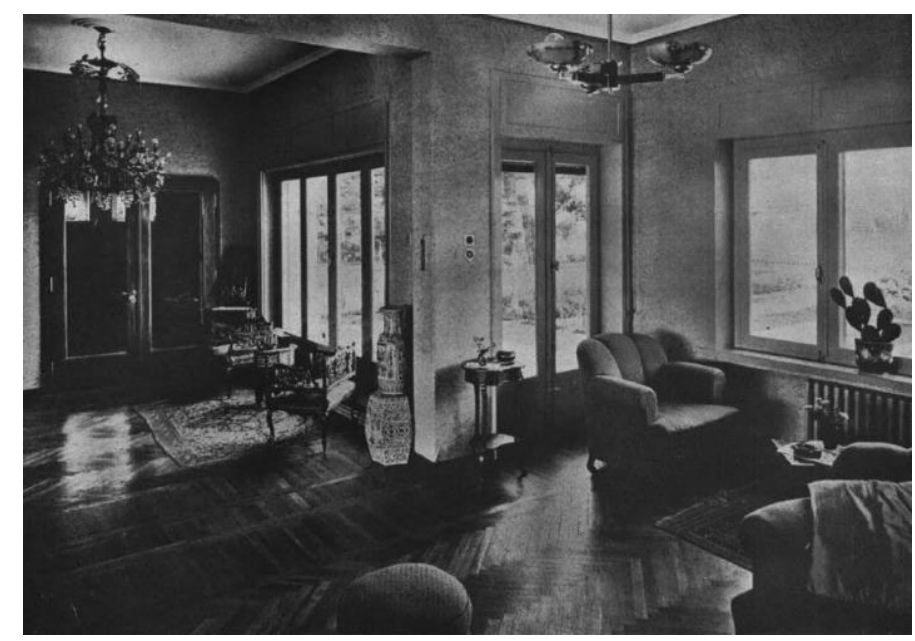

Resim 14. Suadiyede villa, Zeki Sayar: Art Deco lamba ile avize aynı karede. (Arkitekt, 1937)

\section{Sonuç}

Cumhuriyet Türkiye'sinin ilk yıllarında elektrik enerjisi ve elektrik teknolojisi rejim bürokratlarının, aydınlarının, mimarlarının ve mühendislerinin tartışmalarında başat bir yere sahipti. Her ne kadar Cumhuriyet rejimi aktörlerinin Türkiye'nin elektriklendirilmesi için verdiği sistematik çabalar pratikte sınırlı kalmış ve hatta zaman zaman elektriğin varlığı ve yokluğu üzerinden toplumsal eşitsizlikleri görünür kılmış olsa da, elektrik enerjisi ve teknolojisi kullanımının Cumhuriyet rejiminin sınai ilerleme, ekonomik kalkınma, ulusal birliktelik 
hedeflerinin somutlaşmasında belirleyici olabileceği düşünülmüştü. Bu dönemde asrileştirilmeye çalışılan evler ise gerek tarihsel süreçlerin doğal bir sonucu olarak geçirdiği mekânsal dönüşümlerle, gerekse ulusal modernleşme anlatılarına paralel ilerleyen modern birey ve ailenin inşası çabalarıyla tartışmalarda önemli rol oynamıştı.

Bu makalede 1920'li yılların sonlarını ve 1930'ları tarihsel zemin alarak ve domestik mekânda elektrikli tenvirat kullanımını teşvik eden resmi ve popüler yayınlardan faydalanarak, uluslararası düzeyde de ilgi konusu olan fennî ve asri ev tartışmalarını anlamaya çalıştık. Farklı amaçlar doğrultusunda hazırlanmış Hakimiyet-i Milliye, Ameli Elektrik, Yedigün veya Arkitekt gibi yayınlarda yer alan asri, rasyonelleştirilmiş ev tartışmalarının elektrikli tenviratı çokça odağına aldığını söyleyebiliriz. Bu dergilerin Türkiye'nin orta ve üst sınıf profiline hitap ettiği ve etki alanının toplumun küçük bir kesimi ile sınırlı kaldığı açıktır. Gündelik hayat ekseninde bu söylemlerin nasıl gerçekleştiğini anlayabilmek için anı, günlük, mektup gibi birinci şahıs anlatılarının yer aldığı kaynaklara başvurmak gerekir, bu da ayrı bir makalenin konusu. Ancak ele aldığımız yayınlar, tartışmalar ve reklamlar şu hususları açığa çıkarıyor.

Henüz yeni bir teknoloji olan elektrik aydınlatması bir "gereksinim" olarak kodlanmış, elektriğin lüks ve pahalı olduğu, kazalara ve tehlikeleri açık olduğu gibi endişeler bertaraf edilmeye çalışımıştır. Elektrikli aydınlatma kullanımının teşvik süreci, yeni rejimin arzuladığı rasyonel, bilimsel, verimli, ölçülü, sıhhatli, hijyenik vatandaş inşası süreciyle paralel ilerlemiş, hatta bu ürünler çağdaş kadın, erkek ve çocuk imgeleri eşliğinde sunularak, rejimin "asrilik" vurgusu böylelikle pekiştirilmek istenmiştir. Burada dikkati çeken noktalardan birisi, ürünler çerçevesinde oluşturulan pazarlama söyleminin genellikle kadın tüketicileri hedeflemesi ve örtük bir biçimde kadının ev işlerine ayırdığı zamanı optimize ederek ve erkeğin ise elektriklendirilmiş alanı bir istirahat mekânı olarak kodlamasını sağlayarak, eşitsiz toplumsal cinsiyet rollerini yeniden ürettiğidir.

Bir diğer önemli nokta, elektrik ışığının gece ve gündüz arasındaki zamansal sınırları muğlaklaştırması ve konut iç mekânını yeniden işlevlendirerek gündelik hayatın ritmini değiştirmeyi hedeflemesidir. Elektrik ışığı, bir yandan zamanın ruhunu evlerin içine taşırken diğer yandan yeni rutinler ve yeni nesnelerin birbiriyle kurduğu işlevsel bağı tamamlayıcı bir rol üstlenmiştir. "Gece hayatı" ile tanışan evlerin içindeki maddi çevrenin yeniden biçimlenmesinde rol oynayan tenviratın işlevi yalnızca görme ve görülmeyi sağlamak değil, aynı zamanda mekândaki ambiyansı düzenlemektir. Yalnızca reklamlar üzerinden verilen mesajlarda değil, asri konut tartışmalarında da sıklıkla karşımıza çıkan görsel konfor ve ambiyans kriterleri, mekânda 
elektrik ışığı gibi teknik bir bileşenin modern insanın psikolojik ihtiyaçlarıyla kurduğu ilginç bağı göz önüne serer. Gerek eşyalar ile kurduğu işlevsel bağlar, gerekse asri evin ruhunu tamamlamaktaki manevi sorumluluğu, elektrik ışığının kendisine yüklenen sembolik anlamın ötesine geçerek günlük hayatın tam manasıyla işleyebilmesi için temel bir gereksinim haline dönüştüğünü bizlere gösterir.

Son olarak dikkatimizi çeken evlerde elektrikli aydınlatma kullanımında öne çıkan tüm bu hususların, sevgi, şefkat, neşe, mutluluk, konfor, zevk, haz gibi insanın iç dünyasına hitap eden duygusal bir içerikle sunulmasıdır. Politik ideolojiler ve teknolojik dönüşümlere içkin ancak çoğu zaman geri plana itilen duyguların, elektrikli tenviratın başrol oynadığı nesneler dünyası ve insan ilişkilerini şekillendirmekte oldukça önemli olduğunu söyleyebiliriz.

\section{ORCID ID}

NURÇIN ILERI

CANSU DEĞIRMENCIOĞLU
(iD) https://orcid.org/0000-0002-2990-8042

(iD) https://orcid.org/0000-0003-1949-3231

\section{Declaration of Conflicting Interests}

The author declared that there were no conflicts of interest with respect to the authorship or the publication of this article.

\begin{abstract}
Çıkar Çatışması Beyanı
Yazar bu makalenin yazarlık veya yayımlanmasına ilişkin olarak hiçbir çıkar çatışması olmadığını beyan etmiştir.
\end{abstract}

\section{KAYNAKÇA}

Akman, A., ve Köksal, G. (2007). Silahtarağa nasıl çalışırdı? A. Aksoy, Silahtarağa Elektrik Santrali: 1910-2004 içinde (s. 63-77). İstanbul: İstanbul Bilgi Üniversitesi Yayınları.

Altunç, S. (1936). Ev Idaresi. İstanbul: Devlet Basımevi.

Akçura, G. (2001). “Konfor Modern.” Ivır Zıvır Tarihi 1 - Unutma Beni. içinde (ss. 37-49) İstanbul: OM Yayınevi.

Akçura, G. (2002). "Işık Sattırır." Ivır Zıvır Tarihi 3 - Uzun Metin Sevenlerden Misiniz? içinde (ss. 127-136), İstanbul: Om Yayınevi.

Ameli Elektrik dergi kapağı. (1932, Mart-Nisan). Ameli Elektrik (54). 
Appadurai, A. (1986). The Social Life of Things, Commodities in Cultural Perspective. Cambridge: Cambridge University Press.

Arel, S. (1936). Taylorisme. İstanbul: Devlet Basımevi.

Arkan, S. (1936, Temmuz). Çankaya'da bir Villa. Arkitekt (67), ss. 179-186.

Asrî bir yatak odası. (1934). Yedigün, 2 (51).

Bahtiyar olmak içün. (1926, Nisan). Ameli Elektrik.

Baltacıoğlu, i. H. (1929). Mimaride kübizm ve Türk an’anesi. Darülfünun Ilahiyat Fakültesi Mecmuası, 3 (11), 110-131.

Bilgin, N. (2011). Eşya ve İnsan. İstanbul: Gündoğan Yayınları.

Bir genç kız ampul takarken elektriklendi ve öldü. (1929, Mart 6). Cumhuriyet, s. 4.

Bir Kaç Tavsiye. (1931, Ekim). Ameli Elektrik (51), s. 304.

Bodanis, D. (2004). Electric Universe: How Electricity Switched on the Modern World. London: Hachette UK.

Bozdoğan, S. (1996). Modern yaşamak: Erken cumhuriyet döneminde kübik ev. Y. Sey (Ed.) içinde, Tarihten Günümüze Anadolu'da Konut ve Yerleşme içinde (ss. 313-328), İstanbul: Tarih Vakfı Yurt Yayınları.

Bozdoğan, S. (1998). "Sıhhatli, Konforlu, Kullanışlı Evler": 1930'lar Mimarlığında Modernlik Söylemi. Osmanlı'dan Cumhuriyet'e problemler, araştırmalar, tartışmalar : 1. Uluslararası Tarih Kongresi, 24-26 Mayıs, 1993, Ankara içinde (ss. 344-352). İstanbul: Tarih Vakfı Yurt Yayınları.

Bozdoğan, S. (2002). Modernizm ve Ulusun Inşası: Erken Cumhuriyet Türkiyesi'nde Mimari Kültür. (T. Birkan, Çev.) İstanbul: Metis Yayınları.

Bozdoğan, S., ve Kasaba, R. (1997). Introduction. S. Bozdoğan, \& R. Kasaba, Rethinking Modernity and National Identity in Turkeyiçinde, Washington, D.C: University of Washington.

Çavdar, T. (1983). Türkiye'de Enerji. Cumhuriyet Dönemi Türkiye Ansiklopedisi içinde. İstanbul: illetişim Yayınları.

Corbusier, L. (1986). Towards a New Architecture. (F. Etchells, Çev.) New York: Dover Publications, Inc.

Delice, S. (2007). Elektrik, Modernleşme ve Kamusal Alan: Silahtarağa Elektrik Santrali. İstanbul Bilgi Üniversitesi.

Dersaadet'in Rumeli cihetiyle mülhakâtında kudretü'l-elektrikiyye tevziât-i umumiyesi. (1920). Conventions et Cahiers des Charges, 1336. Constantinople: Zellitch Freres, Pera, Rue Yazidji. 
Dinçel, A. (1973). "Türkiye'de Elektriklendirme Hizmetlerinin Anı ve Belgelerle Tarihçesi", 50. Yıl. (ss. 87-115). Ankara: Türkiye Elektrik Kurumu.

Elektrik Cereyanına Kapıldı. (1930, Mart 16). Cumhuriyet, s. 6.

Elektrik Tenviratı Pahalı Değildir. (1931, Eylül-Ekim). Ameli Elektrik, s. 305.

Elektrik, Gaz, Su, Tramvay, Rıhtım ve Hava Nakliyatı. (1933, Ekim 29). Hakimiyet-i Milliye, s. 36.

Engin, V., ve Gülsoy, U. (2010). Elektriğin Istanbul'a Girişi, Teknolojik ve Toplumsal Katkıları. İstanbul: TÜBITAK, Proje No: 107K053.

Erkan, S. (1935, Mayıs). Kira Evi. Arkitekt (53), ss. 129-140.

Eski Ev, Yeni Ev. (1930, Mayıs 3). Hâkimiyet-i Milliye, s. 6.

Evi asrileştirmek için. (1929, Mart). Ameli Elektrik (34), s. 97.

Evinizi ziya ile güzelleştiriniz. (1931, Eylül-Ekim). Ameli Elektrik (51).

Fevzi, H. (1934). Güneşin Saltanatı. Yedigün, 2 (39), s. 10-11.

Ford Fabrikasında Bir Mühendis Elektriklendi. (1930, Ocak 14). Cumhuriyet, s. 4.

Forty, A. (1995). Objects of Desire, Design and Society Since 1750. London: Thames and Hudson.

Galip, R. (1929, Şubat 2). Doktor der ki: "Kızıl". Cumhuriyet, s. 3.

Georgeon, F. (2006). Sultan Abdülhamid. (A. Berktay, Çev.) İstanbul: Homer Kitabevi.

Gooday, G. (2008). Domesticating Electricity: Technology, Uncertainty and Gender, 1880-1914. London: Pickering \& Chatto.

Gözlerinizi Koruyun. (1932, Mart-Nisan). Ameli Elektrik (54).

Gupta, A. (2015). An Anthropology of Electricity from the Global South. Cultural Anthropology, 4 (30), 555-568.

Hughes, T. H. (1993). Networks of Power: Electrification in Western Society, 1880-1930 . Maryland: John Hopkins University Press.

Ileri, N. (2017). Allure of the Light, Fear of the Dark: Nighttime Illumination, Spectacle, and Order in Fin-de-Siècle Istanbul. Comparative Studies of South Asia, Africa and the Middle East, 2 (37), 280-298.

Işıkpınar, H. H. (1931, Mayıs). Evlerin Elektrik Tertibatı. Arkitekt, 1 (5), ss. 175-178.

Işıkpınar, H. H. (1933). Cumhuriyet Türkiyesi, Elektrikli Türkiye. İstanbul: Fazilet Matbaası.

Istanbul Şehri Tenvirat İstatistiği 1923-1932. (1934). İstanbul: İstanbul Belediye Matbaası.

İstanbulda elektrik kuvvei muharrikesinin hali hazırı. (1929). Ameli Elektrik 1929 Almanağı, s. 40.

İstatistik Yıllığı (1931-1932). İstatistik U. M. Neşriyatından: 5 (21), İstanbul: Devlet Matbaası. 
İyi bir tenvir elde etmek için. (1932, Mart-Nisan). Ameli Elektrik (54), s. 40-41.

İyi Tenvir. (1929, Eylül). Ameli Elektrik (39), ss. 216-217.

Kafadar, C. (2014). How Dark Is the History of the Night, How Black the Story of the Coffee, How Bitter the Tale of Love: The Changing of Measure of Leisure and Pleasure in Early Modern Istanbul. A. Öztürkmen, \& E. B. Vitz (Ed.), Medieval and Early Modern Performance in the Eastern Mediterranean içinde (ss. 243-271). Turnhout: Brepols.

Kanıpak, Ö. (1998). Modernism and dwelling: residential architecture in early republican Turkey. (Yüksek lisans tezi) Massachusetts Institute of Technology.

Karaca, N. (2000). Pozitivizmin Erken Cumhuriyet Dönemine Etkisi. Ankara: Anı Yayınları.

Karaosmanoğlu, Y. K. (2004). Ankara. İstanbul: İletişim Yayıncılık.

Karateke, H. (2015). Illumination Ottoman Ceremonial. S. Blair, \& J. Bloom, God Is the Light of the Heavens and the Earth: Light in Islamic Art and Culture içinde (ss. 282-307). New Haven: Yale University Press.

Kaya, ì. (t.y.). Cumhuriyetin Onuncu Yıl Hatıraları. TBMM Arşivi.

Köse, Y. (2016). Dersaadet'te Tüketim (1855-1923). İstanbul : Tarih Vakfı Yayınları.

La Foire Internationale D'Izmir. (1936, Ekim). La Turquie Kamâliste (15), ss. 15-19.

Lefebvre, H. (2007). Modern Dünyada Gündelik Hayat. (K. Şahin, Ed., \& I. Gürbüz, Çev.) İstanbul: Metis Yayınları.

Mithat, A. (2001). Avrupa Adab-ı Muaşeret Yahut Alafranga. (i. Doğan, \& A. Gurbetoğlu, Ed.) Ankara: Akçağ Yayınları.

Modern Bir Ev Nasıl Döşenmelidir? (1929, Temmuz 20). Hâkimiyet-i Milliye, s. 5.

Mutfak. (1931, Eylül-Ekim). Ameli Elektrik (51), s. 315.

Mutfakta Elektrik Ziyası. (1932, Kanunusâni-Şubat). Ameli Elektrik (53), ss. 15-16.

Navaro-Yaşın, Y. (2000). "Evde Taylorizm": Türkiye Cumhuriyeti'nin ilk yıllarında evişinin rasyonelleşmesi (1928-40). Toplum ve Bilim(84) (Ş. Özden, Çev.), 51-74.

Nye, D. E. (1990). Electrifying America : Social Meanings of a New Technology, 1880-1940. Cambridge: MIT Press.

Osram. (1930, Aralık 27). Evinizi daha iyi tenvir suretile güzelleştiriniz! Cumhuriyet, s. 6.

Osram. (1931, Eylül-Ekim). Mutfağını daha iyi tenvir et! Ameli Elektrik (51).

Osram. (1931, Kasım-Aralık). Ziyadan tasarruf yanlış tasarrufdur. Ameli Elektrik (52).

Osram. (1932, Kasım-Aralık). Ziyadan Iktisat Etme! Ameli Elektrik (58).

Osram. (1937, Şubat 27). Tenvirat Reçetesi no.5. Yedigün (207).

Osram. (1937, Mart 10). Tenvirat Reçetesi no.7. Yedigün (209). 
Öztaner, E. (2016). Technology as a multi-directional construction: Electrification of Istanbul in the late nineteenth and early twentieth centuries. (Yayımlanmamış doktora tezi) İstanbul Şehir Üniversitesi.

Satie firmasının tanıtım toplantısı. (1930'lar). Suna ve İnan Kıraç Vakfı (SVIKV), IAE, CFA_2353.

Şavk, B. E. (2014). Servant Princess of the Modern Home: Domesticity and Femininity in Turkey after Electrification, 1923-1950. (Yayımlanmamış doktora tezi) Ankara: İhsan Doğramacı Bilkent Üniversitesi.

Sayâr, Z. (1937, Ekim-Kasım). Suadiye'de Bir Villa. Arkitekt (82-83), s. 269-274.

Sezgin, C. (2011). Sanayi Devrimi'nin Etkisinde Imparatorluk'tan Cumhuriyet'e Türkiye. İstanbul: Arçelik.

Tanyeli, U. (1996). Osmanlı Barınma Kültüründe Batılılaşma-Modernleşme: Yeni Bir Simgeler Dizgesinin Oluşumu. Y. Sey (Ed.) Tarihten Günümüze Anadolu'da Konut ve Yerleşme içinde (ss. 284-297). İstanbul: Tarih Vakfı Yurt Yayınları.

Tenvir Daimî Tenviratı. (1934, Ekim). Ameli Elektrik (67), s. 8.

Tenvirat. (1930, Mayıs-Haziran). Ameli Elektrik (43), s. 64.

Turan, G. (2009). Türkiye'de Erken Cumhuriyet Dönemi Zanaat Ve Endüstri Üretiminde Tasarım. (Yayımlanmamış doktora tezi) İstanbul: İstanbul Teknik Üniversitesi.

Umûmî Nüfûs Tahrîri, 28 Teşrinievvel 1927, Ankara

(https://archive.org/details/umumnfustahriri20004tu/page/n2/mode/2up) erişim tarihi 14.09.2020.

Ünsal, B. (1939). Kübik Yapı ve Konfor. Arkitekt, 9 (3-4), ss. 60-62.

Vanini, P. (2009). Material Culture and Technology in Everyday Life. New York: Peter Lang Publishing.

Wishnitzer, A. (2014). Shedding New Light: Outdoor Illumination in Late Ottoman Istanbul. J. Meier, U. Hasenöhrl, \& K. Krause, Urban Lighting, Light Pollution, and Society içinde (ss. 66-84). London: Routledge.

Yazman, M. Ş. (1933). Elektrikli Türkiye. Kadro Aylık Fikir Mecmuası (13), ss. 35-41.

Yücel, A. (1996). İstanbulda 19. yüzyılın Kentsel Konut Biçimleri. Y. Sey (Ed.) içinde, Tarihten Günümüze Anadolu'da Konut ve Yerleşme (ss. 298-312). İstanbul: Tarih Vakfı Yurt Yayınları.

Ziya ve Rüyet. (1929, Eylül). Ameli Elektrik (39), ss. 225-226. 


\title{
Sonnotlar
}

\begin{abstract}
' Bu tarz çalışmaların gündelik hayatta ev içi mekânların yeniden organizasyonunda ne kadar etkili olup olmadığı halen bir muamma, ancak fikirsel düzeyde bu tartışmaların Osmanlı toplumunda epeyce yer ettiği aşikâr. Uğur Tanyeli bu tarz çalışmaların gündelik hayat pratiklerinde çok da yeri olmadığını ve "wishful thinking"den öteye gidemediğini iddia eder (Tanyeli, 1996, s. 294).
\end{abstract}

ii Osmanlı Devleti'nin liman kentlerinde su, aydınlatma, tramvay gibi altyapı yatırımlarında yabancı sermayenin hâkim olması ve Osmanlı bürokratlarının bir tekel oluşturabilecek yabancı sermaye hâkimiyetine sıcak bakmaması, aynı zamanda hali hazırda gaz şirketlerine verilen uzun dönemli imtiyazlar ve elektrik şirketlerinin devreye girmesiyle çıkar çatışmalarının yaşanma ihtimali bu şüphecilikte önemli rol oynamıştı. Elektriğin kendinden önceki teknolojilere kıyasla -ücreti, aydınlatma gücü, sağlığa etkisi, tehlike (yangın) potansiyeli- avantajları ve dezavantajlarının da henüz netlik kazanmamış olması bu şüpheciliği besleyen bir unsur olarak karşımıza çıkar. Osmanlı şehirlerinin fiziki yapısının da elektrik altyapısı için uygun olmadığı da dile getirilen bir unsurdur. Son olarak, Sultan II. Abdülhamid'in elektrik teknolojisini kendi iktidarını tehdit eden bir unsur olarak gördüğü, elektrik kullanılarak kendisine suikast düzenleneceği korkusu dolayısıyla da bu teknolojinin Osmanlı coğrafyasına, özellikle de İstanbul'a gelişini geciktirdiği, dönemin yazarları tarafından iddia edilmektedir.

iii “Dersaadet'in Rumeli cihetiyle mülhakâtında kudretü'l-elektrikiyye tevziât-i umumiyesi," Conventions et Cahiers des Charges, 1336 (Constantinople: Zellitch Freres, Pera, Rue Yazidji, 1920).

iv 1888 yılında, İstanbul'da Tersane-i Amire Elektrik Fabrikası kurulmuştur, ancak bu fabrika kent ölçekli olmaktan uzaktır ve ordunun ihtiyaçlarını karşılamak amacıyla kurulmuştur. Şunu da belirtmek gerekir ki, bu dönemde kent ölçekli bir elektrik santralinin veya bir elektrik altyapı şebekesinin henüz bulunmaması, elektriğin hiç kullanılmadığı anlamına gelmez. Bağlı bulundukları yabancı elçilikler aracılığıyla bazı sermaye sahipleri veya ufak girişimciler, kendi ihtiyaçlarını karşılamak amacıyla, legal veya illegal yollarla, jeneratörler ve elektrikli aletler ithal edebilmişlerdir. Ayrıca bazı okullar, hastaneler ve konsoloslukların da elektrik kullandığına dair kaynaklar mevcuttur. Yıldız Sarayı'nda kullanılmak üzere elektrikli aletlerin ithal edildiği ve sarayda bu aletleri denetleyen bir elektrik heyetinin bulunduğunu da karşımıza çıkan bilgiler arasındadır. Fakat genel olarak bu dönemde elektrik kullanımının toplumun oldukça küçük ve elit bir tabakasıyla sınırlı kaldığını söyleyebiliriz.

${ }^{\vee}$ Yünlü kumaş üreten Feshane ve yine 1929-1933 arası ihracat yönelimli otomobil montajına devam eden Ford Motor Company'nin Tophane Fabrikası, Elektrik Şirketi'nin ilk sanayi müşterileri arasındaydı. Çimento fabrikası, fırınlar, dokuma fabrikaları, buz imalathaneleri, balık işletme fabrikaları, sigara fabrikası ve küçük atölyeler, elektrikle beslenen üretim kuruluşlarına eklenmişti.

vi 1924'te Ankara; 1925'te Adana, Akşehir, Artvin, İnebolu, İzmir, Mersin, Trabzon; 1926'da Aksaray, Ayvalık, Bursa, İzmit, Konya, Kütahya, Malatya, Sivas; 1928'de Afyon, Antalya, Çorum, Eskişehir, Giresun, Kırkağaç, Kırklareli, Nazilli, Samsun, Yozgat; 1929’da Bafra, Bandırma, Biga, Milas, Ordu; 1930'da Balıkesir, Kastamonu, Tekirdağ ve Urfa elektrik santrallerini kavuşmuştu (Çavdar, 1983, s. 691).

vii Yael Navaro-Yaşın, bu ifadeleri ünlü bir enstitü öğretmeni olan Süheyla Arel'in 1936 yılında yayımladığı Taylorisme adlı kitabından aktarmaktadır. 